LL. BANCO CENTRAL DO BRASIL

\title{
Informational Switching Costs, Bank Competition and the Cost of Finance
}

José Renato Haas Ornelas, Marcos Soares da Silva and Bernardus Ferdinandus N. Van Doornik

January 2020

(Version updated in April 2020)

Working Papers
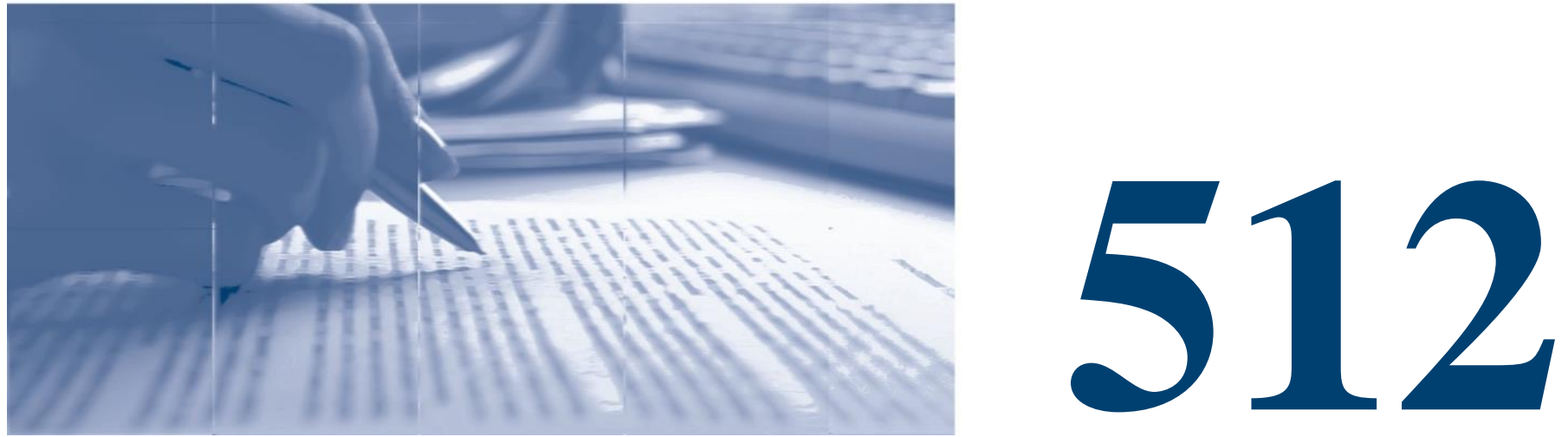


\section{Working Paper Series}

Edited by the Research Department (Depep) - E-mail: workingpaper@bcb.gov.br

Editor: Francisco Marcos Rodrigues Figueiredo

Co-editor: José Valentim Machado Vicente

Head of the Research Department: André Minella

Deputy Governor for Economic Policy: Fabio Kanczuk

The Banco Central do Brasil Working Papers are evaluated in double blind referee process.

Although the Working Papers often represent preliminary work, citation of source is required when used or reproduced.

The views expressed in this Working Paper are those of the authors and do not necessarily reflect those of the Banco Central do Brasil.

As opiniões expressas neste trabalho são exclusivamente do(s) autor(es) e não refletem, necessariamente, a visão do Banco Central do Brasil.

\section{Citizen Service Division}

Banco Central do Brasil

Deati/Diate

SBS - Quadra 3 - Bloco B - Edifício-Sede - $2^{\circ}$ subsolo

70074-900 Brasília - DF - Brazil

Toll Free: 08009792345

Fax: +55 (61) 3414-2553

Internet: http//www.bcb.gov.br/?CONT ACT US 


\section{Non-Technical Summary}

In this paper, we empirically test the two theoretical paradigms in the area of banking competition - the market power hypothesis and the information hypothesis - by evaluating the links between market power and spreads of loans to firms in Brazil.

The market power hypothesis claims that higher market power leads to financial constraints and higher spreads. On the other hand, the information hypothesis argues that banks need some market power to reduce the information asymmetry problem in lending markets. According to the information hypothesis, a lower competition induces banks to engage in relationship lending to obtain greater soft information, thus reducing information asymmetries. Under this view, a higher level of competition reduces the attractiveness of relationships and increases the cost of credit.

Using a proprietary dataset of over 13 million observations of private commercial banks loans to firms of all sizes from 2005 to 2016, our empirical results show an inverse relationship between competition and spreads, supporting the market power hypothesis.

Furthermore, we investigate how the relationship between banks and firms is associated with spreads by analyzing switching costs of bank clients and the lock-in effect. Another key empirical finding is the characterization of the "capture then extract rents" behavior in Brazil. Private banks engage in a strategy of first capturing some of their clients by offering them lower interest rates, and then extracting rents by increasing interest rates as the relationship evolves. This suggests that informational switching costs are helping banks to hold firms as clients. This evidence is also against the information hypothesis.

Our results are stronger for micro and small firms than for medium and large firms, which reinforces our findings since smaller firms tend to be more affected by market power and lock-in effects.

Given this diagnosis, policy responses related to foster information sharing may help to decrease switching costs and alleviate the effects of lock-in. 


\section{Sumário Não Técnico}

Neste artigo, testam-se empiricamente dois paradigmas teóricos na área da competição bancária - a hipótese do poder de mercado e a hipótese da informação avaliando as relações entre o poder de mercado e os spreads nos empréstimos a empresas no Brasil.

A hipótese do poder de mercado afirma que um maior poder de mercado leva a restrições financeiras e spreads mais altos. Por outro lado, a hipótese da informação argumenta que os bancos precisam de algum poder de mercado para reduzir o problema de assimetria de informação no mercado de empréstimos. De acordo com a hipótese de informação, uma competição mais baixa induz os bancos a criarem um relacionamento com as empresas para obter mais informações e, assim, reduzir a assimetria de informação. Sob esse ponto de vista, um nível mais alto de concorrência reduz a duração e a força dos relacionamentos e assim aumenta o custo do crédito.

Usando dados do SCR (Sistema de Informações de Crédito) com mais de 13 milhões de observações em nível de empréstimos para empresas por parte de bancos comerciais privados de 2005 a 2016, os resultados empíricos mostram uma relação inversa entre concorrência e spreads, dando suporte à hipótese do poder de mercado.

Além disso, investiga-se como a duração do relacionamento entre bancos e empresas está associada com os spreads, analisando os custos para os clientes de trocar de banco e o efeito de lock-in. Documenta-se empiricamente o comportamento de "capturar e extrair renda" no Brasil pelos bancos privados. Esses adotam uma estratégia de primeiro capturar alguns de seus clientes, oferecendo-lhes taxas de juros mais baixas, e, em seguida, extrair rendas por meio do aumento das taxas de juros à medida que o relacionamento evolui. Isso sugere que a informação obtida sobre os clientes durante o relacionamento torna custosa a troca de banco, e isso ajuda os bancos a manterem as empresas como clientes. Essa evidência também é contrária à hipótese da informação.

Os resultados são mais fortes para micro e pequenas empresas do que para médias e grandes empresas, o que reforça as conclusões, uma vez que empresas menores tendem a ser mais afetadas pelo poder de mercado e pelos efeitos de lock-in.

Esse diagnóstico corrobora políticas relacionadas ao compartilhamento de informações, as quais podem ajudar a diminuir os custos informacionais de se trocar de banco e assim reduzir o efeito de lock-in. 


\title{
Informational Switching Costs, Bank Competition and the Cost of Finance*
}

\author{
José Renato Haas Ornelas **
}

Marcos Soares da Silva ${ }^{* *}$

Bernardus Ferdinandus Nazar Van Doornik**

This version: April 2020

\begin{abstract}
This paper studies the links between competition in the lending market and spreads of bank loans in Brazil. Evidence from a dataset of more than 13 million loan-level observations from private banks shows a positive relationship between market power, measured by the Lerner Index, and the cost of finance, measured by spreads over the treasury curve. Furthermore, there is evidence of the holdup problem, originated from informational switching costs faced by firms. Private banks engage in a strategy of first competing fiercely for clients by offering a lower loan interest rate and later increasing interest rates as the bank-firm relationship duration increases. Both results are stronger for micro and small firms than for medium and large firms.
\end{abstract}

Keywords: banking; competition; switching costs; information asymmetry; holdup problem; lock-in.

JEL Classification: D43; G21; L10; L14.

The Working Papers should not be reported as representing the views of the Banco Central do Brasil. The views expressed in the papers are those of the author(s) and do not necessarily reflect those of the Banco Central do Brasil.

\footnotetext{
* We are grateful to the useful comments from Andrew Powell, Cesar Tamayo, Hans Degryse, Oscar Carvallo and other participants of the Inter-American Development Bank's working group "Banking Competition and the Cost of Credit in Latin America". We would like also to thank comments from Alvaro Pedraza, Andre Minella, Carlos Viana de Carvalho, Clodoaldo Annibal, Fabiana Carvalho, Fábio Kanczuk, Gabriel Garber, Ilan Goldfajn, João Manoel Pinho de Mello, Sergio Lago Alves, Sergio Mikio Koyama, Thiago Christiano Silva and participants of internal seminars at the Central Bank of Brazil and at the Catholic University of Brasília. We are also indebted to comments from participants of the Bank of England workshop "Big data empirics and policy analysis", including our discussant Julia Ushakova; from the BCB Research Network Workshop, specially our discussant Vicente Gama; and from the International Workshop on the Cost of Credit, particularly our discussant Lars Norden.

${ }^{* *}$ Research Department, Banco Central do Brasil.
} 


\section{Introduction}

Competition is a recurrent and controversial topic in the banking literature. On the one hand, the most prominent theoretical paradigm in the area of banking competition is the market power hypothesis. According to this hypothesis, higher market power leads to financial constraints and higher spreads. On the other hand, the information hypothesis challenges the market power hypothesis, arguing that banks need some market power to reduce the information asymmetry problem in lending markets (Petersen and Rajan, 1995). According to the information hypothesis, a lower competition induces banks to engage in relationship lending (see, for instance, Kysucky and Norden, 2016) to obtain greater soft information, thus reducing information asymmetries. Under this view, a higher level of competition reduces the attractiveness of relationships and increases the cost of credit.

Another strand of the literature focuses on the switching costs clients face during their relationship with banks (see Klemperer, 1995; and Degryse et al., 2009, section 4.1.4). These costs may allow banks to extract rents from locked-in clients. A possible behavior is the so-called "capture then extract rents", where banks first aggressively compete for clients, and, once established the relationships increase loan interest rates above marginal costs to compensate possible initial losses.

In this paper, we evaluate these hypotheses by analyzing the links between market power (competition) in the lending market and spreads of loans to firms. Also, we investigate how the relationship between banks and firms affects spreads. We conduct the empirical investigation in a major emerging economy: Brazil. We believe Brazil serves as the right laboratory for the study since bank loans in Brazil are known to have the highest loan interest rate and spreads among the major economies, and this has been concerning economists and policy-makers for a long time. Higher intermediation costs constrain access to credit and keep lending levels low. The reasons for this may include lack of competition and the holdup problem.

We use a proprietary dataset of over 13 million observations of private commercial banks ${ }^{1}$ loans to firms of all sizes from 2005 to 2016 . The use of data at loan level allows us to better disentangle demand and supply factors. Our empirical investigation shows an inverse relationship between competition and spreads, supporting

\footnotetext{
${ }^{1}$ Private commercial banks are responsible for most of the loans $(60 \%)$ for firms in Brazil in the credit line of our sample. Section 2.2 explains the motivation of using only private banks.
} 
the market power hypothesis. Furthermore, we find a positive association between bankfirm relationship duration and spreads charged by private banks. This evidence is consistent with informational switching costs creating hurdles for clients to change their bank. In this way, banks would first capture the client and then extract rents. Both results are evidence against the information hypothesis.

Our results show a direct relationship between market power (measured by the Lerner Index) and spread, so that higher competition decreases the cost of firm financing, in line with the market power hypothesis. Loans located on the last quintile of the Lerner Index distribution have a spread approximately 1.8 percentage points (p.p.) higher than those on the first quintile, in a specification with bank and firm fixed effects. Although economically relevant, this estimate is only a fraction of the mean spread in our sample (25.30 p.p.).

We compare our results with those found in Van Leuvensteijn et al. (2013) and Fungáčová et al. (2017). Both of them use European data to analyze the relationship between competition measures and the cost of credit, in a similar approach when compared to ours. However, they found contrasting results regarding the relationship between competition and the cost of credit. Van Leuvensteijn et al. (2013) find that higher competition (measured by the Boone indicator) reduces interest rate spreads for most loan products from European banks. This result is consistent with our empirical findings for the Brazilian market. However, Fungáčová et al. (2017) use a large dataset of firm-level data to conclude that competition (measured by the Lerner Index and H-statistic) increases the cost of credit. This is not in line with our results.

We believe that our detailed data allows us to better identify shocks when compared with Van Leuvensteijn et al. (2013) and Fungáčová et al. (2017), as we have loan-level information, including the bank-firm relationship over time. Furthermore, we use a competition measure - Lerner Index - at bank-level, instead of country-wide measures. This allows us to benefit from heterogeneity both on bank cross-section and time-series.

Another key empirical finding of our paper is the characterization of the "capture then extract rents" behavior, which is linked to the holdup problem. This behavior was previously documented by Ioannidou and Ongena (2010) using data from Bolivia. In our sample, private banks capture clients by offering lower interest rates to new clients, i.e., those who recently opened an account. Loans from firms switching to a private bank with no previous relationship have a spread around 0.5 percentage point lower than renewing 
the loan with the same bank. When switching back to a bank with an existing relationship, firms face a spread 21 basis points higher than the renewing case. Therefore, switching costs seem to be associated with information asymmetry.

After capturing the client, private banks seek to increase interest rates. There is a positive association between the duration of the bank-firm relationship, measured both in years and in number of loans, and spreads. The sixth loan of a bank-firm relationship has a spread half percentage point higher than the first one, while the $15^{\text {th }}$ loan has a spread one percentage point higher than the first loan. This increasing spread also affects firms after switching to a new private bank. Therefore, we find evidence against the information hypothesis. Even though private banks can gather soft information during the relationship with the firm, reducing information asymmetry, these efficiency gains are not passed along to clients. This is evidence of imperfect competition, probably due to informational loan-switching barriers.

Both empirical findings - market power and relationship duration - affect more intensively micro and small firms than medium and large firms, in line with the literature (see Chong et al., 2013; and Ryan et al., 2014). The effect of market power is 3.3 times stronger on micro firms than on medium and large firms. The intensity of the effects on spreads from the bank-firm relationship is much higher for micro and small firms, no matter if we measure the relationship by number of years or number of loans.

The remaining of this paper is structured as follows. Section 2 describes the credit market in Brazil. Section 3 presents the variables used to study the relationship between bank competition and spreads, while Section 4 provides the main statistics of the sample. Section 5 analyzes the dynamics of our competition measure - the Lerner Index - over the sample period. Section 6 shows empirical results using bank-specific Lerner Index and spreads. Section 7 characterizes the "capture then extract rents" behavior by private banks. Section 8 concludes the paper.

\section{Characteristics and evolution of credit markets in Brazil}

The banking credit market in Brazil grew from 25\% of GDP at the beginning of 2005 to almost $50 \%$ of GDP at the end of 2016. Among the possible drivers for this increase are the declining trend of the policy interest rates, several regulatory microeconomic reforms - such as the payroll credit rules in 2003 , the fiduciary lien 
reform in 2004, and the bankruptcy reform in 2005, among others - and also a fostering credit policy by the Federal government after the global financial crisis of 2008 .

The presence of a substantial amount of subsidized credit is possibly the key difference of the credit market in Brazil when compared to other major economies. These subsidies come from the government, especially at the federal level. However, only a small share of firms has access to these loans. Brazil also has a substantial amount of the so-called earmarked credit, where specific sources of funding (e.g., saving accounts) must be used to a specific type of credit (e.g., real estate financing). At the end of our sample, the proportion of the credit market for firms, which can be freely allocated by banks, represented $49 \%$ of the total.

We can also characterize the Brazilian credit market by its types of players. Besides private banks - both local and foreign - there is a strong participation of public (state-owned) banks ${ }^{2}$. In some situations, public banks are oriented to achieve public policy objectives, such as increasing credit availability.

Credit unions, in turn, are financial institutions that seek to achieve their associates' goals. Although credit unions are small institutions, there is a large number of them in Brazil, and they are organized in federations in order to reduce costs and increase efficiency.Moreover, credit unions usually operate in market niches that are not served by large institutions. In these niches, they seem to have market power since their Lerner index is on average higher than those of larger institutions. Apparently, competing for clients in these underserved markets is a strategy for small institutions.

It is important to cite that some private foreign banks recently exited the Brazilian retail credit market to concentrate their operations on wholesale, probably searching for a market niche. Lack of scale efficiency may have influenced this strategic decision.

\section{Variables}

\subsection{Spread}

We measure spread at loan-level as the difference between the interest rate charged by banks to borrowers on a specific loan and the treasury curve rate for the same maturity of the loan. Thus, we do not consider the spot or policy interest rate, but a rate

\footnotetext{
${ }^{2}$ We refer to public or state-owned banks as those controlled by the central or subnational governments.
} 
compatible with the maturity of the loan. This absorbs the term premium ${ }^{3}$ from spreads, making our measure more likely to reflect what banks consider as a funding source. Note also that our measure does not consider deposit rates, but rather the Treasury curve. Therefore, the focus is on competition in the lending market, but not in the deposit market.

\subsection{Competition Measures}

In the traditional Structure, Conduct, and Performance (SCP) paradigm, the structure of the market causes performance (see Bain, 1951). Thus, market power would be a consequence of (possibly implicit) collusion or entry barriers, leading to high concentration and profitability. In this way, a high concentration would lead to high market power, less competition, and higher spreads. Thus, concentration is considered a measure of competition under the SCP view.

The New Empirical Industrial Organization (NEIO) challenges this view, arguing that it ignores the conduct of banks, relying only on the structure of the market. Then, instead of using concentration, new ways of measuring competition arise, such as the Lerner index, the H statistics of Panzar and Rosse (1987) and the Boone Indicator (Boone, 2008). Indeed, concentration and competition measures may be uncorrelated or even positively correlated (Martins, 2012; Silva, 2014; Claessens and Laeven, 2004). In this paper, we use the Lerner index as our primary measure of market power, but we also consider traditional concentration measures.

We calculate the Lerner Index for each bank $i$ in each quarter $q$ :

$$
L_{i q}=\frac{P_{i q}-M C_{i q}}{P_{i q}}
$$

where the price $P_{i q}$ is the financial intermediation revenue as a percentage of outstanding credit (without loan provisions) for bank $i$ in quarter $q$ and $M C_{i q}$ is the marginal cost calculated using a trans-log cost function using the methodology described in the Appendix.

The bank-specific Lerner index is a measure of market power of that institution, and it is calculated every quarter. The Lerner index used in this paper is restricted to the credit business of banks so that it does not reflect the mark-ups of other business lines such as trading and other services. Banks with high market power will have a high Lerner

\footnotetext{
${ }^{3}$ Term premium can be defined as the difference between the yield of a long-term bond and the market's expectation for the short-term rate from today to the maturity of the long-term bond.
} 
index since they are able to charge prices well above marginal cost. The Lerner index can be interpreted as a measure of the mark-up that banks can impose on their clients.

One of the assumptions of the Lerner index is profit-maximization behavior by financial institutions. Without such an assumption, the Lerner index can no longer be interpreted as market power (Spierdijk and Zaouras, 2017). However, in the Brazilian credit market, some institutions may not seek profit maximization. This is the case of credit unions $^{4}$, which may have a minimum profit constraint, but do not actually seek maximization (see Vervliet, 2015, for a similar discussion). This might also be the case of public banks, at least during some years of the sample. Silva and Pirtouscheg (2015) report that, around 2012, Brazilian Federal Government fostered public banks to reduce their spreads "putting pressure" on private banks to also decrease theirs, giving a boost to the Credit/GDP ratio.

For this reason, it is not clear whether these banks are profit maximizers in our sample. Therefore, we restrict our sample to the private commercial banks, for which Lerner Index is likely to measure the market power. These banks are responsible for most of the loans $(60 \%)$ for firms in Brazil in the credit lines of this research.

\subsection{Control Variables}

Besides the competition measures and the spread, we use several control variables related to the loan, to the firm and the bank.

The loan-related variables are the following:

- Collateral: is a dummy variable that takes the value of one if there is collateral for loans from bank $b$ to firm $i$ in month $t$, and zero otherwise.

- Loan Amount: is the $\log$ of the loan amount from bank $b$ to firm $i$.

- Loan Rating: are dummies variables for the rating of the loan from bank $b$ to firm $i$ at time $t$ attributed by the bank. There are nine ratings, but we consider only the top four ratings, which accounts for most of the observations. The base-case is the worst rating.

- Loan maturity: is the loan time to maturity measured in months.

We have information about the firm, gathered by banks:

\footnotetext{
${ }^{4}$ Credit unions are small institutions, usually focused on a geographical region or type of associate.
} 
- Firm Age: is the log of the firm age in years.

- Firm Size (Credit Registry): are dummies variables for firm size at time $t$ attributed by the bank. There are four sizes and the base-case for these dummies is when the bank does not inform this variable.

- Firm Location: are dummies variables for the geographic location of firm $i$ at time $t$. This is composed of the first two digits of the Brazilian postal code system (in Portuguese, CEP - Código de Endereçamento Postal).

- Firm Activity (Industry): are dummies variables for the main economic activity of the firm in that month, based on the first three digits of the $\mathrm{CNAE}^{5}$ classification system. There are 633 economic activities in the sample.

Regarding the relationship between the bank and the firm, we use the following variables:

- Bank-Firm Relationship years: measures the relationship between bank $b$ and firm $i$. It is the log of the relationship's number of years.

- \# of open current accounts: is the number of current accounts that a firm has in a given month.

We also use concentration measures, based on the geographic and location levels:

- Herfindahl-Hirschman Index (HHI): It is calculated by summing the square of the market share $M S_{b, g, t}$ from each financial institution on a specific market $m$ and in each month $t$. The market is based on three alternative definitions: geographic location (the first two digits of the Brazilian postal code system), industry (first three digits of the CNAE), and the interaction of geographic location and industry:

$$
H H I_{m, t}=\sum_{b} M S_{b, m, t}^{2}
$$

\section{Sample}

The sample is a merger of two datasets with different periodicities: monthly loanlevel data and quarterly bank accounting data. Our main sample has loan-level observations for new loans from private commercial banks to firms registered in the Credit Registry maintained by the Central Bank of Brazil , from 2005 to 2016, identifying

\footnotetext{
${ }^{5}$ The CNAE is the official economic activity classification system used by the Statistics National System. We consider the CNAE version 2.0. More information available at: https://ww2.ibge.gov.br/english/estatistica/economia/classificacoes/cnae2.0/default.shtm
} 
the firm, the bank and the month. We consider only new loans above $\mathrm{R} \$ 5,000$ for nonfinancial privately-held firms, using the bank's own funding resources ${ }^{6}$.

There is a wide range of credit lines types in Brazil, and some of them are very heterogeneous. Thus, in our sample, we restrict them to three main types of credit lines for firms: working capital, receivables discounting, and vehicles.

For each loan, the spread of the interest rate over the Treasury yield curve considers the maturity of the loan. In order to clean data reporting errors, we exclude negative spreads. Furthermore, we exclude, for each month, the top and bottom $2.5 \%$ spreads to avoid outliers.

The treated sample has a total of 13.7 million loans, and around $63 \%$ of these loans have collateral. All analyses are carried out considering financial conglomerates level or individual institutions that do not belong to a conglomerate. Thus, we have 136 private commercial banks and about 2.2 million firms in the sample.

Table I shows summary statistics for loans. We can see the high level of spreads in Brazil, about 25.3 p.p. p.a. The loan amount is highly asymmetric, with a mean of 92 thousand reais and a median of 15 thousand. The average maturity is around one year, with a median of just six months, characterizing this sample as short-term loans.

\section{Table I - Loan Summary Statistics}

\begin{tabular}{|c|c|c|c|c|c|}
\hline & Mean & $\begin{array}{l}\text { Standard } \\
\text { Deviation }\end{array}$ & $\begin{array}{c}\mathbf{2 5}^{\text {th }} \\
\text { Percentile }\end{array}$ & $\begin{array}{c}5^{\text {th }} \\
\text { Percentile }\end{array}$ & $\begin{array}{c}{75^{\text {th }}}^{\text {Percentile }}\end{array}$ \\
\hline \multirow{5}{*}{$\begin{array}{l}\text { Spread (p.p. per } \\
\text { year) } \\
\text { Amount (R\$) } \\
\text { Maturity (months) }\end{array}$} & 25.30 & 18.07 & 12.59 & 20.87 & 32.27 \\
\hline & $92,044.68$ & $1,059,282$ & 7,744 & 15,639 & 40,751 \\
\hline & 11.71 & 12.91 & 2 & 6 & 19 \\
\hline & \multicolumn{5}{|c|}{ Spread (p.p. per year) } \\
\hline & \# Loans & Mean & $\begin{array}{c}2^{\text {th }} \\
\text { Percentile }\end{array}$ & $\begin{array}{c}5^{\text {th }} \\
\text { Percentile }\end{array}$ & $\begin{array}{c}{75^{\text {th }}}^{\text {Percentile }}\end{array}$ \\
\hline \multirow{3}{*}{$\begin{array}{l}\text { Working Capital } \\
\text { Receivables } \\
\text { Discounting } \\
\text { Vehicles }\end{array}$} & $7,010,635$ & 33.29 & 18.49 & 29.14 & 43.43 \\
\hline & $5,398,059$ & 18.84 & 11.90 & 17.33 & 24.39 \\
\hline & $1,324,952$ & 9.40 & 6.09 & 8.68 & 11.81 \\
\hline
\end{tabular}

The sampe has loan-level observations for new loans from private commercial banks to firms registered in the Credit Registry maintained by the Central Bank of Brazil, from 2005 to 2016. In includes only new loans above $R \$ 5,000$ for non-financial privately-held firms, using the bank's own funding resources. There are three type of credit lines: Working Capital, Receivables Discounting and Vehicle financing.

\footnotetext{
${ }^{6}$ Subsidized credit is not considered.
} 
We also have information about the size, industry, and geographical location of each firm coming from the Credit Registry. For each bank, we have the balance sheet and income statement information. Regarding loan information, we have the risk rating, the maturity, the amount, and the presence of collateral (binary dummy). The relationship strength between banks and firms is measured by the number of years of the relationship.

Regarding the loan rating, the Central Bank of Brazil requires financial institutions to assign a rating for each loan in the Credit Registry. Each rating is associated with a minimum loan accounting provision, which should be an estimate of the probability of default. Brazilian regulation also requires that loans in arrears should be assigned a low rating. In a small percentage of our sample, we have ratings compatible with loans in arrears. We exclude these loans of our sample to avoid problems of "evergreening", i.e., when the financial institution grants another loan to substitute a loan in arrears or similar situation.

The size of the firms comes from information collected from banks in the Credit Register. There are five categories for size in the Credit Registry. Size zero means the banking institution did not fill the field for the firm size. Sizes 1 to 4 are increasing on the firm size.

In our main regression specifications, we use fixed effects for firms, banks, loan rating, and time $x$ type of credit. However, a significant percentage of firms in the sample have just one loan in the sample, and thus using firm fixed effects will exclude them from estimation. This may create a bias towards medium and large firms since smaller firms tend to be the majority of those with just one loan in the sample. On the full sample, using firm's fixed effects excludes about one million observations, which represents $6.24 \%$ of loans and $38 \%$ of firms. In order to check for robustness, we also use alternative specifications with firm characteristics instead of firm fixed effects, and results are still robust.

We also compare results from this main sample with a sample of loans from stateowned banks, which comprises around 5.9 million loans of 13 banks. These banks are owned either by the federal government or by sub-national governments.

\section{Evolution of the Competition Measure}

In this section, we show the evolution of our competition measure - the Lerner Index - through time. Figure I shows the median, $25^{\text {th }}$ and $75^{\text {th }}$ percentiles of the Lerner 
Index for each quarter, from private commercial banks. The $75^{\text {th }}$ percentile is closer to the median than the $25^{\text {th }}$ one, meaning a left-skewed distribution. In general, even the $25^{\text {th }}$ percentile lies above zero during most of the sample, meaning most of the private banks have some market power.

Figure I - Lerner Index Percentiles - Private Commercial Banks

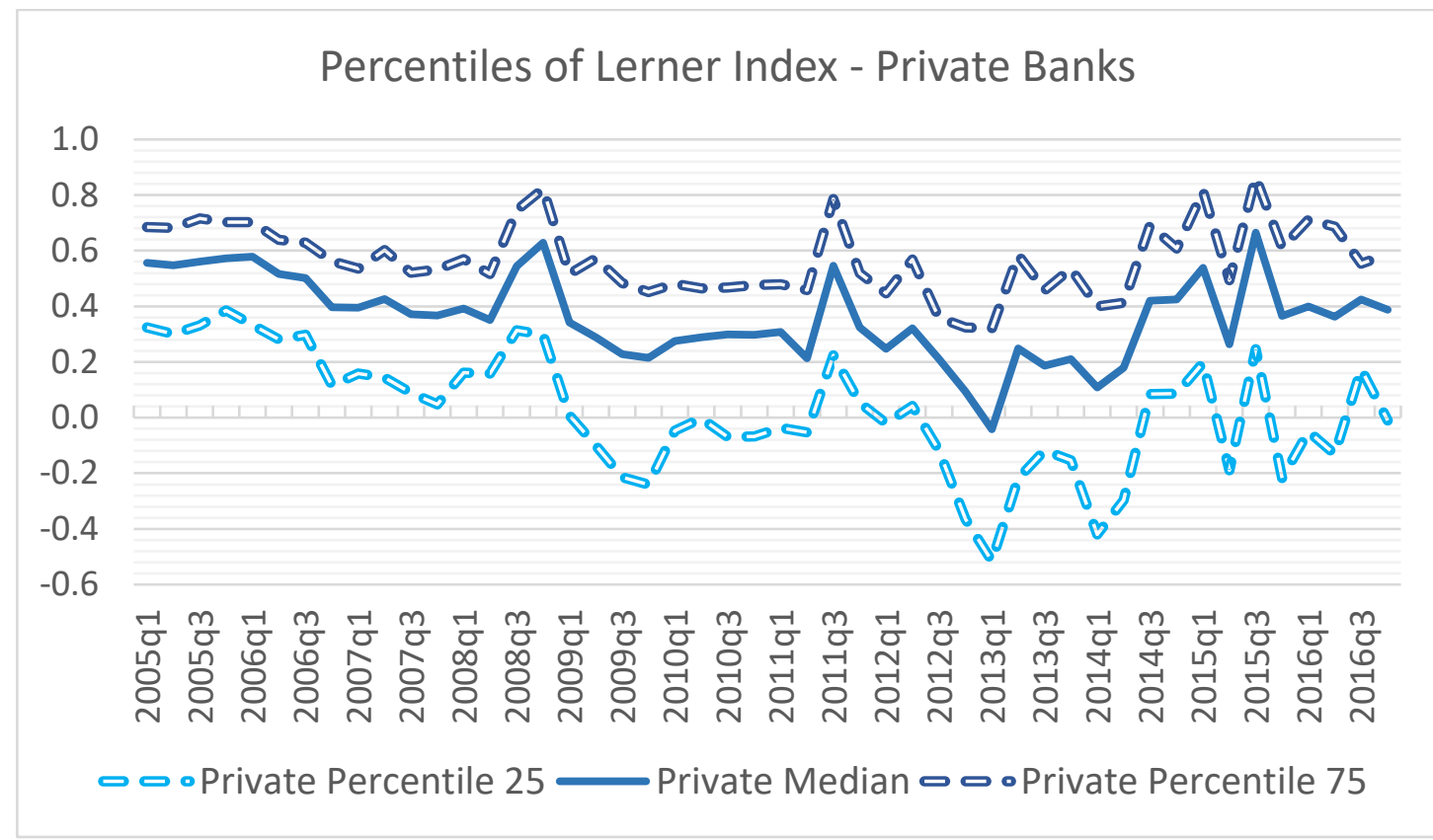

The median Lerner index from private banks has a declining trend from the beginning of the sample in 2005 to the first quarter of 2013, decreasing from 0.56 in 2015 Q1 to -0.04 in 2013 Q1. This picture is consistent with the "put pressure" episode reported by Silva and Pirtouscheg (2015), since the median Lerner index of private banks reached a value near zero in 2013, meaning that roughly half of the banks had a price below marginal cost. In Figure I, we can see that the $25^{\text {th }}$ percentile went deep into the negative values during this episode, reaching -0.38 . These negative mark-ups for roughly onefourth of the private banks last several quarters. After some quarters, mark-ups recovered, and median values recovered in the last quarters of the sample.

Another interesting result of this estimation is that small and medium private banks have higher Lerner index than large private banks. ${ }^{7}$ This may seem counterintuitive, but we provide two possible explanations. First, small and medium

\footnotetext{
${ }^{7}$ The monthly average Lerner index form small private banks is 0.37 , against 0.27 from medium banks, and -0.12 for large banks.
} 
banks in Brazil avoid competing directly with large banks. Therefore, they search for market niches where large banks are not present, and then firms are underserved in terms of credit. On those niches, they may be able to exert market power, since competition from large banks is absent. The second possible explanation is that the "put pressure" affected large private banks since public banks in Brazil are large and compete mainly against large private banks. Thus, the effect of this episode on the Lerner index may be more intense for large than for smaller banks.

\section{Spreads and Bank-Specific Market Power}

In this section, we investigate the relationship between competition and spreads. We use the bank-specific Lerner Index as a measure of competition, which can be interpreted as the market power of that individual institution.

Our baseline specification is the following:

$$
s_{l, b, i, t}=\beta_{1} L_{b, t}+\Lambda \mathbf{C}_{l, \boldsymbol{b}, \boldsymbol{i}, \boldsymbol{t}}+\mathbf{\Phi} \mathbf{R}_{\boldsymbol{b}, \boldsymbol{i}, \boldsymbol{t}}+\mu_{i}+v_{b}+\tau_{t}+\varepsilon_{l, b, i, t},
$$

where:

$s_{l, b, i, t}$ is the spread of loan $l$, from bank $b$ to firm $i$ in month $t$;

$L_{b, t}$ is the Lerner index of bank $b$ in month $\mathrm{t}$. As accounting data is available on a quarterly basis, the Lerner index of that quarter is repeated for all months;

$\mathbf{C}_{l, \boldsymbol{b}, \boldsymbol{i}, \boldsymbol{t}}$ is a set of loan-level characteristics for loan $l$, from bank $b$ to firm $i$ in month $t$. These characteristics are the following: the log of the loan amount in Brazilian reais, a dummy indicating the presence of collateral in the loan, dummies for the loan rating, the maturity of the loan in months and the loan indexing;

$\mathbf{R}_{b, i, t}$ is a set of bank-firm relationship characteristics. These characteristics are the $\log$ of relationship length between bank $b$ and firm $i$ in years; and the number of current accounts firm $i$ has in that month, regardless of the bank;

$\mu_{i}$ are firm fixed effects;

$v_{b}$ are bank fixed effects;

$\tau_{t}$ are monthly fixed effects for each type of credit; and

$\varepsilon_{l, b, i, t}$ is the error term. 
Table II shows the baseline specification in column 1, while more saturated specifications are in columns 2 to 4 . Column 5 shows the baseline specification using only the observations of the most saturated specification of column 4. The estimation procedure is by OLS using the high dimensional fixed effects of Correia (2017), and the estimated standard errors are clustered at the bank-time level. Only new loans from private banks are considered in this table, given the profit maximization issue of the Lerner index, but the results including state-owned banks ${ }^{8}$ are provided in the appendix. Our sample has only new loans from three types of credit for firms: working capital, receivables discounting and vehicle financing.

Results of our baseline specification in column 1 show a statistically positive Lerner index coefficient. Therefore, the market power, measured by the ability of private banks to price loans above marginal cost (i.e., Lerner Index) is associated with higher spreads. This is empirical evidence against the information hypothesis. The coefficient is numerically small. We leave the economic interpretation of this result for the next section, where we use dummies for the Lerner Index levels.

In columns 2, 3, and 4 of Table II, we saturate the model by including more stringent fixed effects (FE). In columns 2 and 4, we replace firm FE by firm x year FE, while in columns 3 and 4, we use bank-year FE instead of bank FE. Recall that our main independent variable, the Lerner index, is calculated every quarter so that using bank $\mathrm{x}$ year FE makes these specifications very saturated.

The motivation to use those fixed-effects comes from the identification problem of demand and supply shocks in the market, which occurs at the same time. The use of firm x time fixed effects helps to overcome this issue, and it is standard in the literature using credit registry datasets (see Jimenez et al., 2014; and Degryse et al., 2019). Our large and detailed dataset allows us to use this approach. Note that using firm x year fixed effects reduces our number of observations by about 2 million $^{9}$, but we still continue with more than 10 million degrees of freedom. The use of bank x time fixed effects also helps with the supply side identification, especially because it allows controlling for banks changing their behavior through time.

\footnotetext{
${ }^{8}$ This robustness test includes commercial public banks, but not development public banks and agencies.

${ }^{9}$ These are mainly observations from firms with just one loan in a given year.
} 
The coefficient of the Lerner index is slightly lower when we use firm $\mathrm{x}$ year fixed-effects (column 2), but it is still significant at $1 \%$ level. When we use bank x year fixed effects (column 3), the point estimate is less than half of the baseline specification, but still significant at $5 \%$ level. Even on our most saturated specification in column 4 , the Lerner index is statistically significant at $5 \%$. Overall, there is robust evidence of a positive relationship between spreads and the Lerner Index.

One issue with using more saturated specifications is whether we are excluding smaller firms since fixed effects with year cut firms with only one observation in a given year. We show in column 5 the same specification of column 1, but using only the observations used in column 4 - the most saturated. In this way, we can check whether the lower coefficients of the Lerner index on the saturated specifications of columns 3 and 4 are due to the exclusion of those smaller firms. We see that the Lerner coefficients of specifications 1 and 5 are the same so that the 2 million observations excluded when we saturate the model are not responsible for the lower Lerner coefficient. In section 6.2 we come back to this issue.

In order to test for possible contemporaneous reverse causality, we re-estimate regressions of Table II using the Lerner index with one-quarter lag. Results (in Appendix I, Table XI) remain very similar to the ones we observe in Table II. Another endogeneity issue is that our dependent variable, the spread, is part of the input used to calculate the Lerner index. This problem is mitigated since we use spreads from the Credit Registry, at the loan level, while market power measures are coming from accounting data, at the bank level. Furthermore, accounting data is based on all outstanding loans of the bank, including those for households, while spreads are restricted to new loans for firms, which correspond to a fraction of all loans of the bank. Besides, the use of numerous fixed effects removes all time-invariant unobservable effects that could potentially affect both bank competition and spreads.

We additionally address the issue of endogeneity in section 6.3 , by considering a normalized measure of market power, further breaking the mechanical relation between spreads and bank-specific Lerner index. Finally, regarding possible concerns with the endogeneity of loan terms (loan purpose, loan amount, maturity, and collateral), we argue 
that loan rates (and spreads) are the last contractual term on which the borrower and the lender agree after all other terms are set $^{10}$.

Regarding the control variables, the results of Table II show that the amount (size) of the loan has a negative and statistically significant coefficient, meaning that banks charge a lower spread for large loans. The presence of collateral coefficient is negative and statistically significant, even though we control for the risk rating of the loan. The negative coefficient is expected since the use of collateral should reduce the risk of the loan, all else constant.

The coefficient of the loan maturity is negative and statistically significant. On the one hand, if long-term loans are riskier than short-term ones, one should expect higher spreads. On the other hand, the required interest rate to restore losses with delinquent debt depends on the default rate and the maturity of the loans. For a given default rate, the lower the term of the loans, the higher should be the interest rate charged to recover the losses with delinquencies. In our case, it seems that the second effect dominates ${ }^{11}$. Besides, the lower spread for longer loans may also occur because only good clients have access to loans with higher maturities.

Regarding the bank-firm relationship, the positive coefficients of the number of years of the bank-firm relationship are consistent with switching costs helping banks "capturing" some of their clients and then extracting rents. The usual reasons for that include habit persistence and the holdup problem. Section 4.1.4 of Degryse et al. (2009) describes this issue:

"Banks can extract higher profits from captured and lock-in (opaque) borrowers than from borrowers that have ready access to other financing alternatives. A switch between banks may entail not only observable direct (transactional) cost of closing an account with one bank and opening a new one elsewhere, but also the unobservable, but perhaps more significant, cost associated with the foregone capitalized value of the (previously established) long-term customer-bank relationship".

\footnotetext{
${ }^{10}$ Standard and Poor's, 2006. A Guide to the loan market https://www.lcdcomps.com/d/pdf/LoanMarketguide.pdf.

${ }^{11}$ In Freixas and Rochet (2008, section 8.6.2), an adapted Merton model is used to analyze the spread. Theoretical model results show that the dependence of $H$ (spread) in $T$ (maturity) is not clear cut. This is in line with our argument that different aspects determine the relationship between spread and maturity.
} 
Table 4.10 A from Degryse et al. (2009) provides a review of the empirical literature regarding the bank-firm relationship duration. Our positive coefficients are in line with those in European markets studies (Belgium, Italy, Spain), but not with those in U.S. studies, which find negative coefficients. In section 7 we come back to this point using dummy variables and test whether banks adopt a strategy of first capturing the client and then extracting rents.

Table II - Bank-specific Lerner Index and Spreads

\begin{tabular}{|c|c|c|c|c|c|}
\hline & $\begin{array}{c}(1) \\
\text { Spread }\end{array}$ & $\begin{array}{c}(2) \\
\text { Spread }\end{array}$ & $\begin{array}{c}(3) \\
\text { Spread }\end{array}$ & $\begin{array}{c}(4) \\
\text { Spread }\end{array}$ & $\begin{array}{c}(5) \\
\text { Spread }\end{array}$ \\
\hline Lerner (Bank Level) & $\begin{array}{c}0.0068^{* * *} \\
(6.21)\end{array}$ & $\begin{array}{c}0.0052 * * * \\
\quad(5.48)\end{array}$ & $\begin{array}{c}0.0021 * * \\
(2.11)\end{array}$ & $\begin{array}{c}0.0019 * * \\
(1.98)\end{array}$ & $\begin{array}{c}0.0068 * * * \\
(6.20)\end{array}$ \\
\hline Log(Loan Amount) & $\begin{array}{c}-4.7697 * * * \\
(-44.44)\end{array}$ & $\begin{array}{c}-4.1699 * * * \\
(-40.81)\end{array}$ & $\begin{array}{c}-4.8238 * * * \\
(-45.16)\end{array}$ & $\begin{array}{c}-4.1989 * * * \\
(-41.09)\end{array}$ & $\begin{array}{c}-4.4531 * * * \\
(-44.84)\end{array}$ \\
\hline Collateral & $\begin{array}{c}-0.3812^{*} \\
(-1.80)\end{array}$ & $\begin{array}{c}-0.5449 * * * \\
(-2.72)\end{array}$ & $\begin{array}{c}-0.7736 * * * \\
(-4.01)\end{array}$ & $\begin{array}{c}-0.6022 * * * \\
(-3.05)\end{array}$ & $\begin{array}{c}-0.3869 * \\
(-1.84)\end{array}$ \\
\hline Loan Maturity & $\begin{array}{c}-0.2798 * * * \\
(-43.65)\end{array}$ & $\begin{array}{c}-0.3064 * * * \\
(-42.04)\end{array}$ & $\begin{array}{c}-0.2815 * * * \\
(-44.35)\end{array}$ & $\begin{array}{c}-0.3103 * * * \\
(-43.00)\end{array}$ & $\begin{array}{c}-0.2957 * * * \\
(-42.99)\end{array}$ \\
\hline $\log (\#$ Accounts $)$ & $\begin{array}{c}0.1381 * * * \\
\quad(4.07)\end{array}$ & $\begin{array}{c}-0.3572 * * * \\
(-8.72)\end{array}$ & $\begin{array}{c}0.0843 * * * \\
\quad(3.08)\end{array}$ & $\begin{array}{c}-0.3516 * * * \\
(-8.82)\end{array}$ & $\begin{array}{c}0.0683 * * \\
(2.12)\end{array}$ \\
\hline $\begin{array}{l}\text { Log(Bank-Firm } \\
\text { Relationship } \\
\text { duration) }\end{array}$ & $\begin{array}{l}0.2077 * * * \\
\quad(9.52)\end{array}$ & $\begin{array}{c}0.2225^{* * * *} \\
(13.35)\end{array}$ & $\begin{array}{c}0.2172 * * * \\
(11.01)\end{array}$ & $\begin{array}{c}0.1787 * * * \\
(11.23)\end{array}$ & $\begin{array}{l}0.1800 * * * \\
\quad(8.04)\end{array}$ \\
\hline $\begin{array}{l}\text { Type of Institution } \\
\text { Adj R }{ }^{2} \\
\text { Fixed Effects }\end{array}$ & $\begin{array}{c}\text { Private Banks } \\
0.6360 \\
\text { Bank, Firm, } \\
\text { loan rating, } \\
\text { Month x type } \\
\text { of credit, } \\
\text { index rate }\end{array}$ & $\begin{array}{l}\text { Private Banks } \\
0.7096 \\
\text { Bank, Firm x } \\
\text { Year, loan } \\
\text { rating, Month } \\
\text { x type of } \\
\text { credit, index } \\
\text { rate }\end{array}$ & $\begin{array}{l}\text { Private Banks } \\
0.6457 \\
\text { Bank x Year, } \\
\text { Firm, loan } \\
\text { rating, Month } \\
\text { x type of } \\
\text { credit, index } \\
\text { rate }\end{array}$ & $\begin{array}{c}\text { Private Banks } \\
0.7137 \\
\text { Bank x Year, } \\
\text { Firm x Year, } \\
\text { loan rating, } \\
\text { Month x type } \\
\text { of credit, } \\
\text { index rate }\end{array}$ & $\begin{array}{c}\text { Private Banks } \\
0.6459 \\
\text { Bank, Firm, } \\
\text { loan rating, } \\
\text { Month x type } \\
\text { of credit, } \\
\text { index rate }\end{array}$ \\
\hline \# Observations & $12,844,901$ & $10,714,238$ & $12,844,856$ & $10,714,190$ & $10,714,190$ \\
\hline \# Bank FE & 130 & 129 & - & - & - \\
\hline \# Firm FE & $1,362,350$ & - & $1,362,346$ & - & $1,008,254$ \\
\hline \# Bank x Year FE & - & - & 941 & 922 & 128 \\
\hline \# Firm x Year FE & - & $2,299,605$ & - & $2,299,594$ & - \\
\hline \multicolumn{6}{|c|}{ 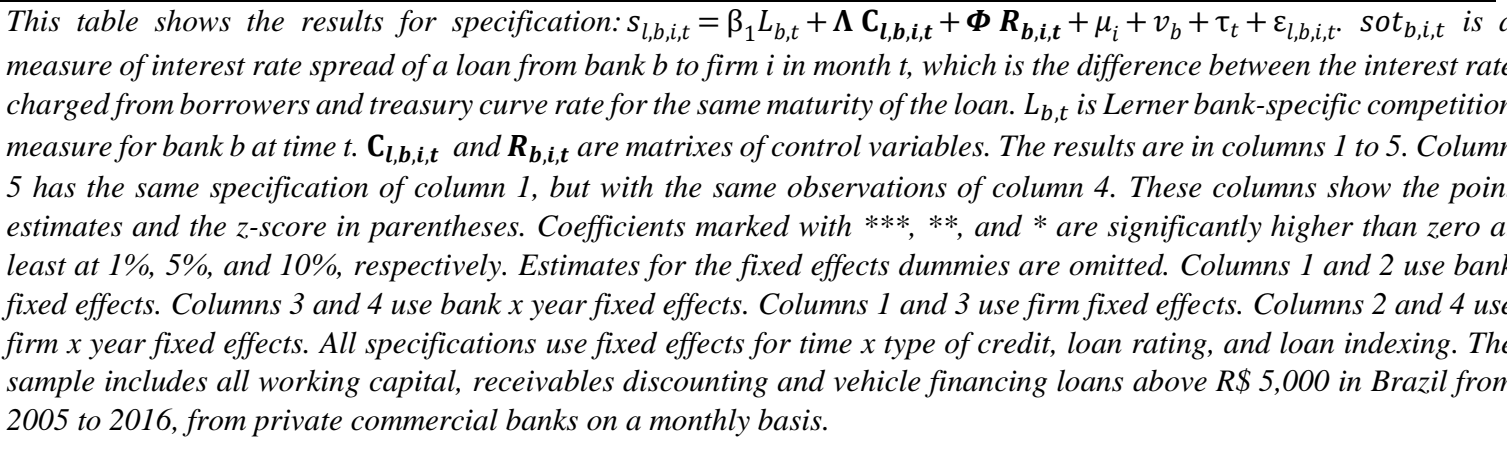 } \\
\hline
\end{tabular}


Table II also considers the (log) number of current accounts of each firm for a given month as a bank-firm relationship control variable. This can be viewed as a measure of competition specifically for that firm, or how financially constrained the firm is. Thus, we would expect a negative coefficient, since firms with more bank relationships would be able to get lower spreads. However, our results are mixed. This coefficient is positive when we use firm fixed effects (columns 1 and 3), and negative when we use firm x time fixed effects (columns 2 and 4) ${ }^{12}$. The expected negative statistically significant coefficient arises only when we strictly account for demand and supply shocks. In section 6.6 we get back to this issue using dummy variables.

Although there is an issue of using the Lerner Index for state-owned banks, Table XII on the appendix presents results considering only commercial state-owned banks. Coefficients for the Lerner index are no longer significant, although they are higher. Interestingly, relationship variables coefficients have different signs when compared to those for private banks. Section 6.6 addresses this issue.

Because of the "put pressure" episode in 2012, we also split the sample in 2012, running regressions for 2005-2011 and 2012-2016 subsamples. The results are qualitatively the same.

Overall, the results in this section support the market power hypothesis against the information hypothesis: first, due to the positive sign of the Lerner Index coefficient; second, because of the positive sign of the bank-firm relationship duration.

\subsection{Specification with Dummies for Market Power}

In this section, we analyze the relationship between competition and spread using dummy variables for market power to facilitate interpretation. We create one dummy variable for each quintile of the Lerner Index distribution for all loans, i.e., considering cross-section and time-series variation. The specifications used are those of Table II, but using dummies for the quintiles of the Lerner Index, instead of the index itself. The basecase dummy is for the first quintile of the Lerner index.

\footnotetext{
${ }^{12} \mathrm{We}$ also use as a measure of bank-firm relationship the number of banks with outstanding loans for that firm on a given month. This measure is specific for credit relationship, while the number of accounts is a broader measure. The sign and significance of coefficients are similar for both measures.
} 
The results are in Table III. In Column 1, we see a monotonically increasing value for dummies, with the second quintile dummy being the only not statistically significant. Being on the fifth quintile of Lerner index means paying around 1.84 percentage points higher spread than the first quintile. This additional spread decreases to 1.31 on the fourth quintile, 1.12 on the third quintile, and 0.7 on the second quintile. Therefore, there is an economically relevant association of market power and spreads, even considering the high level of spreads with an unconditional mean above $20 \%$. It is worth noting that, due to the use of bank and firm fixed effects, the total magnitude of market power coefficients may be underestimated.

When we turn to more saturated specifications, in columns 2 to 4 , the dummy variables estimates decrease. The dummy for the fifth quintile is still significant, but the overall structure is not monotonically increasing anymore. Now the fourth quintile dummy is lower than the third quintile, but both are still higher than the first two quintiles. Although weaker than the baseline, results for very saturated specifications still provide support for a positive relationship between spreads and competition. In Table XIII of the appendix, we re-estimate specification (2) distinguishing by bank size. The effect of the Lerner index on spreads are higher for big banks than for smaller banks. Therefore, although smaller banks might have a higher Lerner index, it has a lower correlation with higher spreads. 
Table III - Spreads and Competition using Dummies

\begin{tabular}{|c|c|c|c|c|}
\hline & $\begin{array}{c}(1) \\
\text { Spread }\end{array}$ & $\begin{array}{c}(2) \\
\text { Spread }\end{array}$ & $\begin{array}{c}(3) \\
\text { Spread }\end{array}$ & $\begin{array}{c}(4) \\
\text { Spread }\end{array}$ \\
\hline $\begin{array}{l}\text { Lerner Quintile } 2 \\
\text { (Between }-0.30 \text { and }-0.11 \text { ) }\end{array}$ & $\begin{array}{l}0.7023 \\
(1.22)\end{array}$ & $\begin{array}{l}0.4197 \\
(1.12)\end{array}$ & $\begin{array}{l}0.3363 \\
(1.17)\end{array}$ & $\begin{array}{l}0.2915 \\
(1.06)\end{array}$ \\
\hline $\begin{array}{l}\text { Lerner Quintile } 3 \\
\text { (Between }-0.11 \text { and }+0.00 \text { ) }\end{array}$ & $\begin{array}{c}1.1247 * \\
(1.73)\end{array}$ & $\begin{array}{l}0.8551^{* *} \\
\quad(2.02)\end{array}$ & $\begin{array}{l}0.8153^{* *} \\
\quad(2.35)\end{array}$ & $\begin{array}{l}0.7294^{* *} \\
\quad(2.31)\end{array}$ \\
\hline $\begin{array}{l}\text { Lerner Quintile } 4 \\
\text { (Between } 0.00 \text { and } 0.16 \text { ) }\end{array}$ & $\begin{array}{l}1.3070 * * \\
(2.18)\end{array}$ & $\begin{array}{l}0.7678 * * \\
\quad(2.06)\end{array}$ & $\begin{array}{l}0.6358 * * \\
(2.07)\end{array}$ & $\begin{array}{c}0.5405^{*} \\
(1.87)\end{array}$ \\
\hline $\begin{array}{l}\text { Lerner Quintile } 5 \\
\text { (Above } 0.16 \text { ) }\end{array}$ & $\begin{array}{l}1.8383^{* * *} \\
\quad(2.74)\end{array}$ & $\begin{array}{l}1.2329 * * * \\
(2.83)\end{array}$ & $\begin{array}{l}1.0527 * * * \\
(2.64)\end{array}$ & $\begin{array}{l}0.8824 * * \\
\quad(2.45)\end{array}$ \\
\hline Log(Loan Amount) & $\begin{array}{c}-4.7720 * * * \\
(-25.96)\end{array}$ & $\begin{array}{c}-4.1707 * * * \\
(-23.79)\end{array}$ & $\begin{array}{c}-4.8240 * * * \\
(-26.37)\end{array}$ & $\begin{array}{l}-4.1992 * * * \\
(-23.93)\end{array}$ \\
\hline Collateral & $\begin{array}{l}-0.4231 \\
(-1.25)\end{array}$ & $\begin{array}{c}-0.5688^{*} \\
(-1.72)\end{array}$ & $\begin{array}{c}-0.7904 * * \\
(-2.56)\end{array}$ & $\begin{array}{c}-0.6169 * \\
(-1.90)\end{array}$ \\
\hline Loan Maturity & $\begin{array}{c}-0.2795 * * * \\
(-26.19)\end{array}$ & $\begin{array}{c}-0.3063 * * * \\
(-24.94)\end{array}$ & $\begin{array}{c}-0.2815 * * * \\
(-26.69)\end{array}$ & $\begin{array}{c}-0.3102 * * * \\
(-25.56)\end{array}$ \\
\hline Log(\# Accounts) & $\begin{array}{l}0.1400^{* * *} \\
\quad(2.68)\end{array}$ & $\begin{array}{c}-0.3517 * * * \\
(-6.55)\end{array}$ & $\begin{array}{l}0.0855^{* *} \\
(2.03)\end{array}$ & $\begin{array}{c}-0.3488 * * * \\
(-6.79)\end{array}$ \\
\hline $\begin{array}{l}\text { Log(Bank-Firm Relationship } \\
\text { duration) }\end{array}$ & $\begin{array}{c}0.2112^{* * *} \\
(6.15) \\
\end{array}$ & $\begin{array}{c}0.2226 * * * \\
(8.37) \\
\end{array}$ & $\begin{array}{c}0.2172 * * * \\
(6.65) \\
\end{array}$ & $\begin{array}{c}0.1780 * * * \\
(7.09) \\
\end{array}$ \\
\hline Type of Institution & Private Banks & Private Banks & Private Banks & Private Banks \\
\hline Adj $R^{2}$ & 0.6362 & 0.7097 & 0.6458 & 0.7137 \\
\hline Fixed Effects & $\begin{array}{c}\text { Bank, Firm, } \\
\text { loan rating, } \\
\text { Month x type } \\
\text { of credit, index } \\
\text { rate }\end{array}$ & $\begin{array}{l}\text { Bank, Firm x } \\
\text { Year, loan } \\
\text { rating, Month x } \\
\text { type of credit, } \\
\text { index rate }\end{array}$ & $\begin{array}{l}\text { Bank x Year, } \\
\text { Firm, loan } \\
\text { rating, Month x } \\
\text { type of credit, } \\
\text { index rate }\end{array}$ & $\begin{array}{c}\text { Bank x Year, } \\
\text { Firm x Year, } \\
\text { loan rating, } \\
\text { Month x type } \\
\text { of credit, index } \\
\text { rate }\end{array}$ \\
\hline \# Observations & $12,844,901$ & $10,714,238$ & $12,844,856$ & $10,714,190$ \\
\hline \# Bank FE & 130 & 129 & - & - \\
\hline \# Firm FE & $1,362,350$ & - & $1,362,346$ & - \\
\hline \# Bank x Year FE & - & - & 941 & 922 \\
\hline \# Firm x Year FE & - & $2,299,605$ & - & $2,299,594$ \\
\hline \multicolumn{5}{|c|}{ 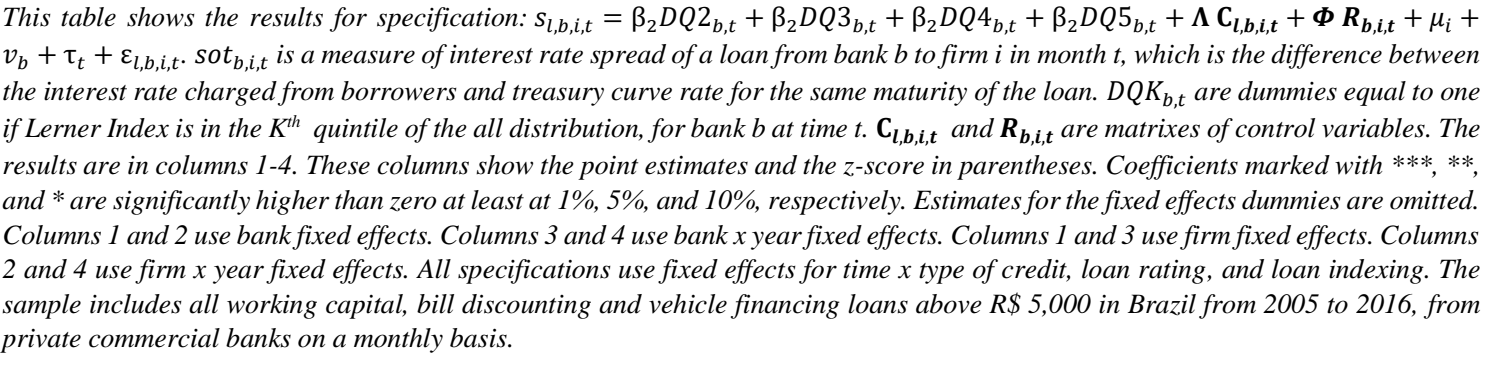 } \\
\hline
\end{tabular}




\subsection{Specification with Firm Characteristics}

Using firm fixed effects is a popular way to control for demand effects. However, it may pose a bias in our sample, as small firms have very few loans during the sample. In fact, $37 \%$ of the firms classified as the lowest size have just one loan in the sample ${ }^{13}$. When we use firm fixed effects, we lose this information, and thus bias our sample towards large firms. When we additionally use firm x year fixed effects, we also lose observations from firms with just one loan in a given year.

Thus, as a robustness check, in Table IV we drop firm fixed effects and replace them with the firm's characteristics. In this way, we are eliminating the large firm bias, while still controlling for demand through firm characteristics. Instead of Firm fixed effects, we use a fixed effect based on several interactions of firm's characteristics. This alternative empirical approach is used by Degryse et al. (2019).

In column 1 of Table IV, we use as fixed effects the interaction of the firm's location and firm's economic activity (around 39 thousand pairs), with an interaction of time $x$ type of credit, and also firm $\operatorname{size}^{14}$. In column 2, we use again the interaction of the firm's location and firm's economic activity, together with a triple interaction of time $\mathrm{x}$ firm size $x$ type of credit (1.7 thousand). In column 3, we use a five-variable interaction of the firm's location, firm's economic activity, firm's size, time, and type of credit, which gives origin to about 1.6 million fixed effects. On all specifications, we use the age of the firm as an additional control. With this setup, we believe to be adequately controlling for firm demand.

The coefficients for the Lerner Index in Table IV are all statistically significant, and their magnitude is similar to those of our baseline specifications in Table II. The less saturated specifications of columns 1 and 2 have a higher coefficient than the baseline model of Table II, while the most saturated specification in column 3 has lower-than-thebaseline estimates. Note that specifications from columns 1 and 2 have around 10 million observations, which is similar to the figures of the most saturated specifications of Table II.

\footnotetext{
${ }^{13}$ For the second-lowest size, 25\% of the firms have just one loan.

${ }^{14}$ We drop loans from firms of unknown size, i.e., where the bank bank did not fill the size field in the registry. This significantly reduces the number of observations.
} 
Table IV - Firm Characteristics, Bank-specific Lerner Index and Spreads

\begin{tabular}{|c|c|c|c|}
\hline & $\begin{array}{c}(1) \\
\text { Spread }\end{array}$ & $\begin{array}{c}(2) \\
\text { Spread }\end{array}$ & $\begin{array}{c}(3) \\
\text { Spread }\end{array}$ \\
\hline Lerner Index (Bank Specific) & $\begin{array}{l}0.0083^{* * *} \\
\quad(6.83)\end{array}$ & $\begin{array}{l}0.0073^{* * *} \\
\quad(7.06)\end{array}$ & $\begin{array}{l}0.0058 * * * \\
(5.93)\end{array}$ \\
\hline Log(Loan Amount) & $\begin{array}{c}-6.0671 * * * \\
(-47.02)\end{array}$ & $\begin{array}{c}-5.9304 * * * \\
(-42.94)\end{array}$ & $\begin{array}{c}-6.3419 * * * \\
(-45.30)\end{array}$ \\
\hline Collateral & $\begin{array}{c}-0.2749 \\
(-1.07)\end{array}$ & $\begin{array}{c}-0.4819 * * \\
(-2.05)\end{array}$ & $\begin{array}{c}-0.6220 * * \\
(-2.19)\end{array}$ \\
\hline Loan Maturity & $\begin{array}{c}-0.2553 * * * \\
(-27.81)\end{array}$ & $\begin{array}{c}-0.2519 * * * \\
(-27.28)\end{array}$ & $\begin{array}{c}-0.2850 * * * \\
(-27.85)\end{array}$ \\
\hline Log(Firm's age) & $\begin{array}{c}-0.9708 * * * \\
(-17.74)\end{array}$ & $\begin{array}{c}-0.9208 * * * \\
(-17.65)\end{array}$ & $\begin{array}{c}-1.0144 * * * \\
(-16.84)\end{array}$ \\
\hline $\log (\#$ Accounts $)$ & $\begin{array}{c}-0.3614 * * * \\
(-7.53)\end{array}$ & $\begin{array}{c}-0.3709 * * * \\
(-7.84)\end{array}$ & $\begin{array}{c}-0.1052 * * \\
(-2.27)\end{array}$ \\
\hline $\begin{array}{l}\text { Log(Bank-Firm Relationship } \\
\text { duration) }\end{array}$ & $\begin{array}{l}0.0931 * * * \\
\quad(3.07)\end{array}$ & $\begin{array}{c}0.0511^{*} \\
(1.72)\end{array}$ & $\begin{array}{l}0.0689 * * \\
(2.06)\end{array}$ \\
\hline $\begin{array}{l}\text { Type of Institution } \\
\text { Adj R }{ }^{2} \\
\text { Fixed Effects }\end{array}$ & $\begin{array}{l}\text { Private Banks } \\
0.4807 \\
\text { Bank, loan } \\
\text { rating, loan } \\
\text { index, location x } \\
\text { industry, time x } \\
\text { type of credit, } \\
\text { firm size }\end{array}$ & $\begin{array}{c}\text { Private Banks } \\
0.4914 \\
\text { Bank, loan rating, } \\
\text { loan index, } \\
\text { location x } \\
\text { industry, time x } \\
\text { type of credit x } \\
\text { firm size }\end{array}$ & $\begin{array}{c}\text { Private Banks } \\
0.4804 \\
\text { Bank, loan rating, } \\
\text { loan index, time x } \\
\text { location x } \\
\text { industry x firm } \\
\text { size x type of } \\
\text { credit }\end{array}$ \\
\hline \# Observations & $9,711,753$ & $9,711,753$ & $6,644,311$ \\
\hline \# Bank FE & 128 & 128 & 125 \\
\hline \# location $\mathrm{x}$ industry $\mathrm{FE}$ & 39,412 & 39,412 & - \\
\hline \# time $\mathrm{x}$ firm size $\mathrm{x}$ credit type FE & - & 1,728 & - \\
\hline $\begin{array}{l}\text { \# time } \mathrm{x} \text { location } \mathrm{x} \text { industry } \mathrm{x} \text { firm } \\
\text { size } \mathrm{x} \text { credit type } \mathrm{FE}\end{array}$ & - & - & $1,599,714$ \\
\hline \multicolumn{4}{|c|}{ 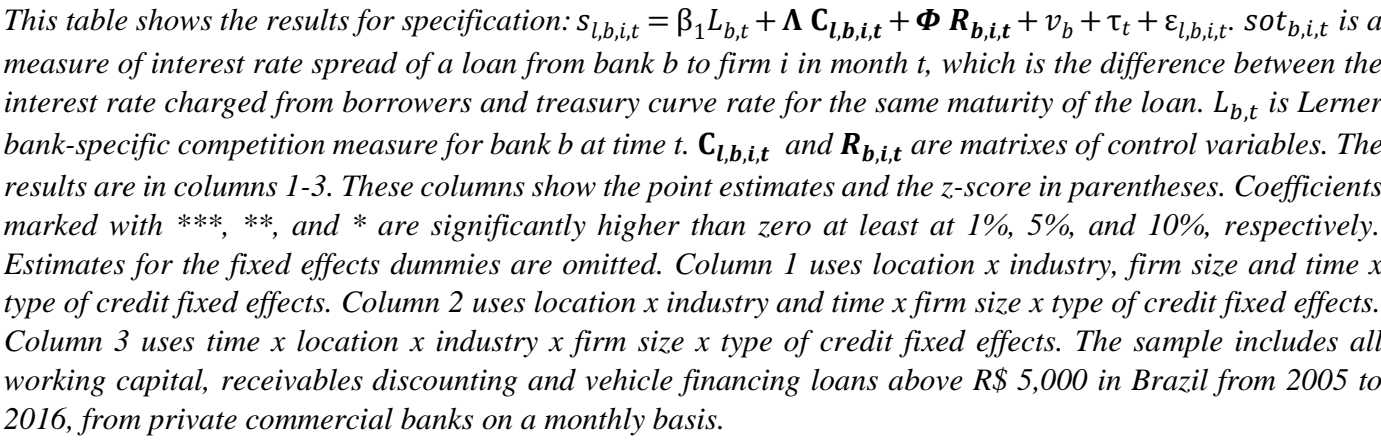 } \\
\hline
\end{tabular}

Furthermore, Table IV shows, as expected, that the age of the firm has a negative and statistically significant coefficient so that older firms pay lower spreads. This is expected as older firms are usually larger, have more historical information available, and 
a business model that survived, at least up to the moment of the credit origination. The $\log$ of the bank-firm relationship duration is still positive and significant.

The coefficient for the log of the number of current accounts is negative, as in the specifications of Table II with firm x year fixed effects. The other control variables - loan amount, collateral, and loan maturity - have coefficients qualitatively similar to our baseline specification.

Overall, this section provides evidence that the use of firm and bank fixed effects on our saturated baseline models does not qualitatively change the results.

\subsection{Market-Adjusted Competition Measure}

In order to further address the issue of endogeneity between spreads and bankspecific Lerner index, we build a variable to measure the average Lerner index from the set of banks operating in a specific "market", excluding from the average the bank which granted the loan. We define "market" in three different ways: geographic location, industry, and their interaction (location $\mathrm{x}$ industry). This variable is calculated for each market $\mathrm{x}$ bank $\mathrm{x}$ month and is denoted by $\bar{L}_{t, m, b}$, where $t$ is the month, $m$ is the market (location, industry, or its interaction), and $b$ is the bank which granted the loan and therefore is excluded from the mean calculation.

As we are excluding from the calculation of this variable the Lerner of the bank who granted the loan, endogeneity issues become less relevant. We use this variable in two robustness exercises: by calculating a normalized Lerner and by using average Lerner $\bar{L}_{t, m, b}$ as an instrument of the bank-specific Lerner.

Our "excess" or "normalized" Lerner is calculated by taking the difference between the bank-specific Lerner and the market-specific excess Lerner $\bar{L}_{t, m, b}$ :

$$
E L_{t, m, b}=L_{b, t}-\bar{L}_{t, m, b}
$$

The econometric specification is the same as of equation (2), which uses firm and bank fixed effects but replacing the bank-specific Lerner by the market-specific excess Lerner considering a relevant market for the firm. Note that the mean Lerner is calculated for all institutions, while the regression is estimated considering only loans from private banks. 
Results are in Table $\mathrm{V}$, and also show positive and statistically significant estimates for the Excess Lerner index in all three definitions of market. The coefficients for the excess Lerner are slightly lower than the one in the first column of Table II. The intuition is that when the market power of the bank is relatively strong when comparing to other banks operating in that market, the bank can charge higher spreads. However, if the bank operates in a market where its competitors have relatively higher market power, it will not be able to charge higher spreads. In this way, there is evidence that the bankcompetitiveness environment of the market in which the firm operates is also relevant for the spread of its loans.

Another robustness check is to instrumentalize our main dependent variable, the bank-specific Lerner, using the average Lerner $\bar{L}_{t, m, b}$ as instrument ${ }^{15}$. Again, we consider three different definitions of market, and results in Table VI are qualitatively the same, with positive and statistically significant coefficients for the Lerner index. In columns 1 and 2, where location and industry are used as market for the instrument, the point estimates are higher than our baseline estimates of Table II, while column 3 has a coefficient slightly lower.

Regarding the validity of the instrument, the Kleibergen-Paap rk Wald F statistic in Table VI rejects the weakness of instruments of columns 1 and 2 with a $10 \%$ significance level. For the instrument in column 3, the significance level is $15 \%$. Overall, the results from Table VI give robustness to our main empirical finding of Table II. The use of a market-adjusted instead of bank-specific Lerner weakens the possible mechanical relationship between spreads and the Lernet index.

\footnotetext{
${ }^{15}$ We argue that banks operating in the same market tend to have a similar behavior in terms of similar Lerner index. However, loan spreads of bank $b$ are not an input for calculating the Lerner of other banks.
} 
Table V - Excess Lerner Index by market and Spreads

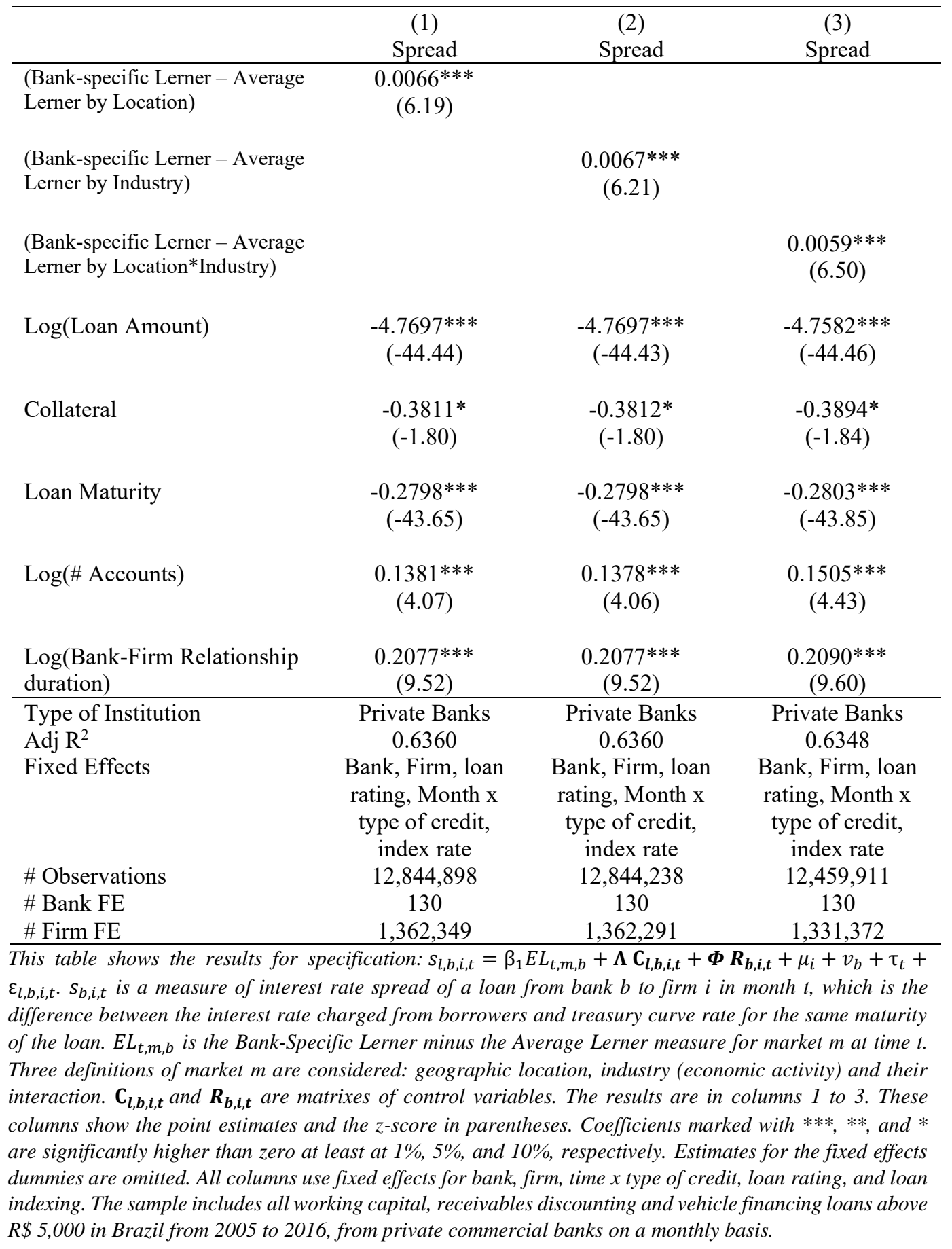


Table VI - Spreads and Lerner using instruments

\begin{tabular}{|c|c|c|c|}
\hline & $\begin{array}{c}(1) \\
\text { Spread }\end{array}$ & $\begin{array}{c}(2) \\
\text { Spread }\end{array}$ & $\begin{array}{c}(3) \\
\text { Spread }\end{array}$ \\
\hline & $\begin{array}{l}\text { Instrument: } \\
\text { Average Lerner by } \\
\text { Location }\end{array}$ & $\begin{array}{l}\text { Instrument: } \\
\text { Average Lerner by } \\
\text { Industry }\end{array}$ & $\begin{array}{c}\text { Instrument: } \\
\text { Average Lerner by } \\
\text { Location } \mathrm{x} \\
\text { Industry }\end{array}$ \\
\hline $\begin{array}{l}\text { Lerner at Bank Level } \\
\text { (using instrument) }\end{array}$ & $\begin{array}{l}0.0075 * * * \\
\quad(4.24)\end{array}$ & $\begin{array}{l}0.0075 * * * \\
\quad(4.07)\end{array}$ & $\begin{array}{l}0.0063 * * * \\
(4.09)\end{array}$ \\
\hline Log(Loan Amount) & $\begin{array}{c}-4.7697 * * * \\
(-44.44)\end{array}$ & $\begin{array}{c}-4.7697 * * * \\
(-44.43)\end{array}$ & $\begin{array}{c}-4.7582 * * * \\
(-44.46)\end{array}$ \\
\hline Collateral & $\begin{array}{c}-0.3811 * \\
(-1.80)\end{array}$ & $\begin{array}{c}-0.3812^{*} \\
(-1.80)\end{array}$ & $\begin{array}{c}-0.3894^{*} \\
(-1.84)\end{array}$ \\
\hline Loan Maturity & $\begin{array}{c}-0.2798 * * * \\
(-43.65)\end{array}$ & $\begin{array}{c}-0.2798 * * * \\
(-43.65)\end{array}$ & $\begin{array}{c}-0.2803 * * * \\
(-43.84)\end{array}$ \\
\hline $\log (\#$ Accounts $)$ & $\begin{array}{l}0.1381 * * * \\
\quad(4.07)\end{array}$ & $\begin{array}{l}0.1378 * * * \\
\quad(4.06)\end{array}$ & $\begin{array}{l}0.1505^{* * *} \\
\quad(4.43)\end{array}$ \\
\hline $\begin{array}{l}\text { Log(Bank-Firm Relationship } \\
\text { duration) }\end{array}$ & $\begin{array}{c}0.2077 * * * \\
(9.52) \\
\end{array}$ & $\begin{array}{c}0.2077 * * * \\
(9.52) \\
\end{array}$ & $\begin{array}{c}0.2090 * * * \\
(9.60) \\
\end{array}$ \\
\hline $\begin{array}{l}\text { Type of Institution } \\
\text { Adj R2 } \\
\text { Kleibergen-Paap rk Wald F } \\
\text { statistic }\end{array}$ & $\begin{array}{c}\text { Private Banks } \\
0.6360 \\
157.47\end{array}$ & $\begin{array}{l}\text { Private Banks } \\
0.6360 \\
117.06\end{array}$ & $\begin{array}{c}\text { Private Banks } \\
0.6348 \\
13.08\end{array}$ \\
\hline $\begin{array}{l}\text { \# Observations } \\
\text { \# Bank FE } \\
\text { \# Firm FE } \\
\end{array}$ & $\begin{array}{c}12,844,898 \\
130 \\
1,362,349 \\
\end{array}$ & $\begin{array}{c}12,844,238 \\
130 \\
1,362,291 \\
\end{array}$ & $\begin{array}{c}12,459,911 \\
130 \\
1,331,372 \\
\end{array}$ \\
\hline \multicolumn{4}{|c|}{ 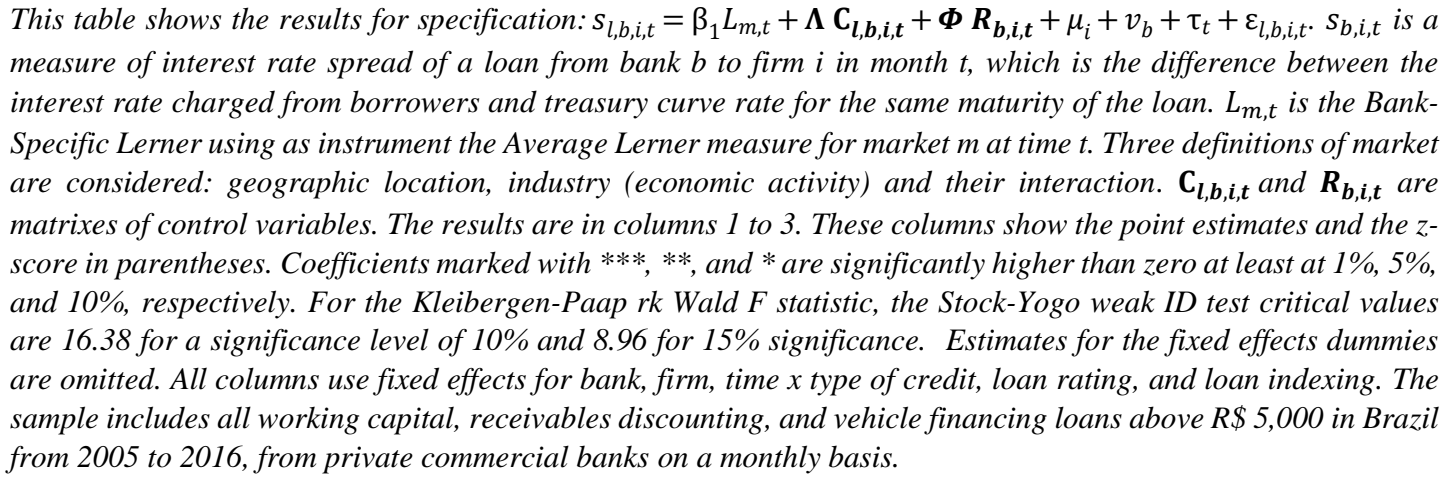 } \\
\hline
\end{tabular}

\subsection{Concentration and Spreads}

In this section, we do a robustness test by adding concentration indexes in our baseline specification to investigate if results for the market power still holds. In this way, we analyze whether the structure of the market also influences spreads.

In order to have data heterogeneity on both cross-section and time-series dimensions, we avoid the use of the overall market concentration index. In this way, we 
measure concentration by calculating the HHI concentration index for each month and for the same three definitions of market used in the previous subsections: geographic location, industry, and their interaction.

For each market definition, the quintiles of HHI concentration indexes distributions are calculated, and then quintiles dummies are created. We add concentration dummies to our specification with dummies shown in Table III of section 6.1. The dummy for the first quintile is the base-case dummy.

These coefficients are shown in Figure II. Panel A considers the HHI by location. Although concentration dummies for third, fourth, and fifth quintiles are positive and statistically significant at $5 \%$, their magnitude is economically small, since it is less than seven basis points in all cases. On the other hand, the Lerner quintile dummies keep the same magnitude of Table III, being several times higher than concentration dummies. If we drop the Lerner index quintiles dummies from this specification, results for the concentration dummies are qualitatively the same.

Panel B of Figure II shows the results for HHI calculated by industry. The sign of the coefficients is now negative, statistically significant, and again with a small magnitude. Finally, Panel C shows estimates for HHI by Location x Industry, and results are mixed, with positive and negative coefficients. On both Panels B and C the coefficients for the Lerner Index dummies are similar in magnitude to our baseline specification. Therefore, results for the Lerner Index are robust to the inclusion of concentration measures. Moreover, it is not clear what the relationship between concentration and spreads is if there is one. 
Figure II - Quintile Dummies Estimates - Concentration and Competition Panel A - Lerner and Location HHI

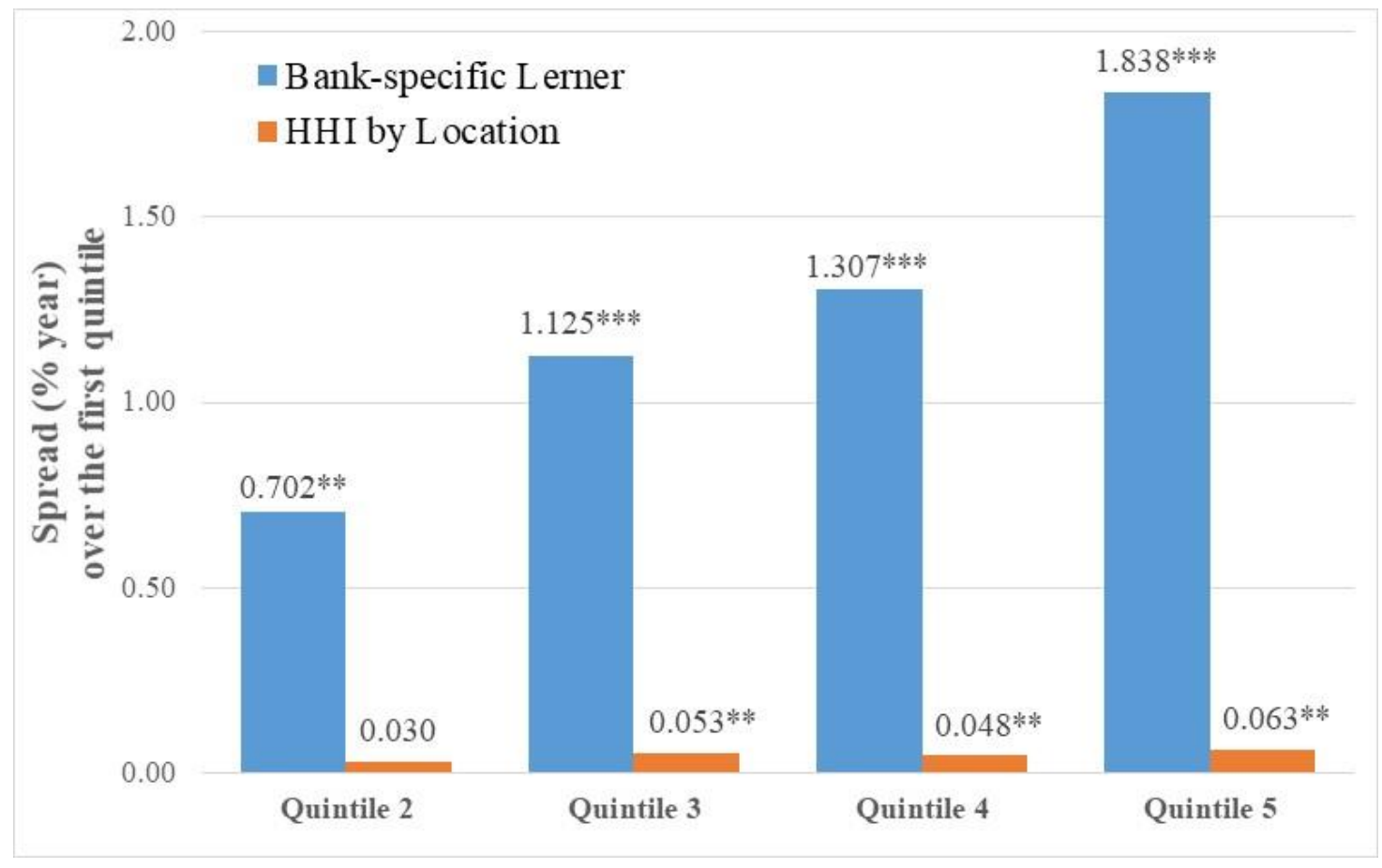

Panel B - Lerner and Industry HHI

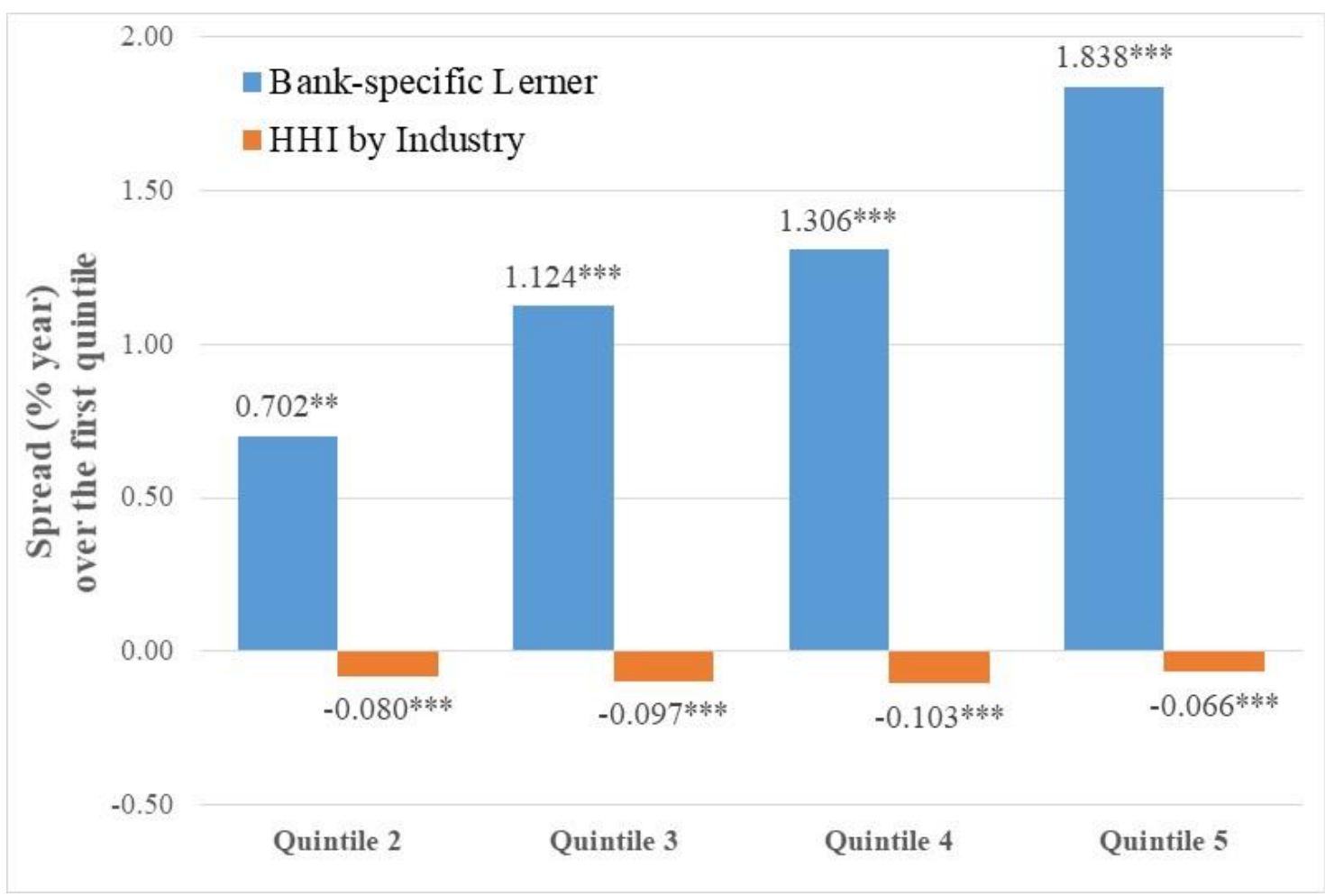




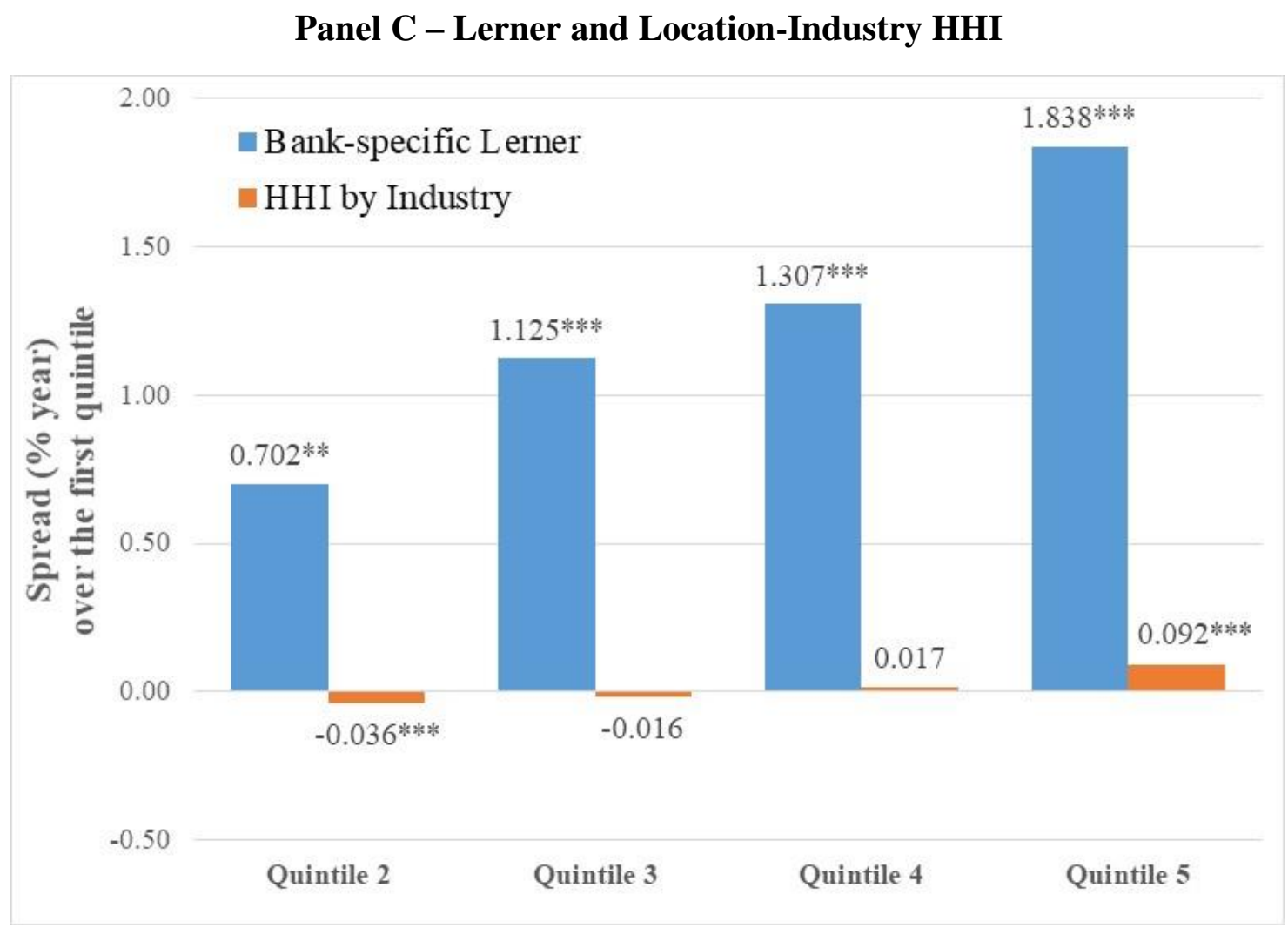

\subsection{Effects by Firm Size}

In this section, we analyze whether the size of the firm matters for the spreadcompetition relationship. We re-estimate results from column 1 of Table II (equation (2)) using three subsamples, according to firm size informed by banks in the Credit Registry: micro firms (Firm size 1), small firms (Firm size 2), and medium/big firms (Firm sizes 3 or 4).

Results are in Table VII. Coefficients of bank-specific Lerner Index decrease with firm size and are all statistically significant. The coefficient for micro firms is about three times higher than for medium and large firms. The coefficient for small firms stands in the mid-way.

This is consistent with better access to finance by larger firms documented in the literature (Carbo-Valverde et al., 2009; Chong et al. 2013; Ryan et al. 2015). While small and medium firms have no alternatives to finance their operations outside the banking system, large firms have a better bargain power, as they can tap capital markets resources through the issuance of bonds. This may explain the lower sensibility of market conditions for large firms. 
Table VII - Bank-specific Lerner Index and Spreads by Firm Size

\begin{tabular}{|c|c|c|c|}
\hline & $\begin{array}{c}(1) \\
\text { Spread }\end{array}$ & $\begin{array}{c}(2) \\
\text { Spread }\end{array}$ & $\begin{array}{c}(3) \\
\text { Spread }\end{array}$ \\
\hline & Micro Firms & Small Firms & Mid/Large Firms \\
\hline Lerner Index (Bank Specific) & $\begin{array}{l}0.0119 * * * \\
(3.20)\end{array}$ & $\begin{array}{l}0.0074 * * * \\
(4.70)\end{array}$ & $\begin{array}{l}0.0036^{* * *} \\
(3.29)\end{array}$ \\
\hline Log(Loan Amount) & $\begin{array}{l}-5.6308 * * * \\
(-19.39)\end{array}$ & $\begin{array}{l}-5.8530 * * * \\
(-32.54)\end{array}$ & $\begin{array}{c}-2.6355 * * * \\
(-25.40)\end{array}$ \\
\hline Collateral & $\begin{array}{c}-0.8374 * * * \\
(-3.39)\end{array}$ & $\begin{array}{c}-0.4173 \\
(-1.48)\end{array}$ & $\begin{array}{c}0.0397 \\
(0.34)\end{array}$ \\
\hline Loan Maturity & $\begin{array}{c}-0.2864 * * * \\
(-26.43)\end{array}$ & $\begin{array}{c}-0.3086 * * * \\
(-38.44)\end{array}$ & $\begin{array}{c}-0.1832 * * * \\
(-25.17)\end{array}$ \\
\hline $\log (\#$ Accounts $)$ & $\begin{array}{l}0.6195 * * * \\
\quad(7.57)\end{array}$ & $\begin{array}{l}0.4501 * * * \\
\quad(8.31)\end{array}$ & $\begin{array}{l}0.1356^{* * *} \\
\quad(2.78)\end{array}$ \\
\hline $\begin{array}{l}\text { Log(Bank-Firm Relationship } \\
\text { duration) }\end{array}$ & $\begin{array}{c}0.5328 * * * \\
(13.14) \\
\end{array}$ & $\begin{array}{c}0.4406^{* * *} \\
(16.25) \\
\end{array}$ & $\begin{array}{l}0.1446^{* * * *} \\
(6.54)\end{array}$ \\
\hline Type of Institution & Private Banks & Private Banks & Private Banks \\
\hline Adj $R^{2}$ & 0.6814 & 0.6125 & 0.5672 \\
\hline Fixed Effects & $\begin{array}{l}\text { Bank, Firm, loan } \\
\text { rating, Month x type } \\
\text { of credit, index rate }\end{array}$ & $\begin{array}{l}\text { Bank, Firm, loan } \\
\text { rating, Month x } \\
\text { type of credit, } \\
\text { index rate }\end{array}$ & $\begin{array}{l}\text { Bank, Firm, loan } \\
\text { rating, Month x } \\
\text { type of credit, } \\
\text { index rate }\end{array}$ \\
\hline \# Observations & $1,265,246$ & $4,616,296$ & $2,685,465$ \\
\hline \# Bank FE & 101 & 111 & 124 \\
\hline \# Firm FE & 383,790 & 697,773 & 197,689 \\
\hline \multicolumn{4}{|c|}{ 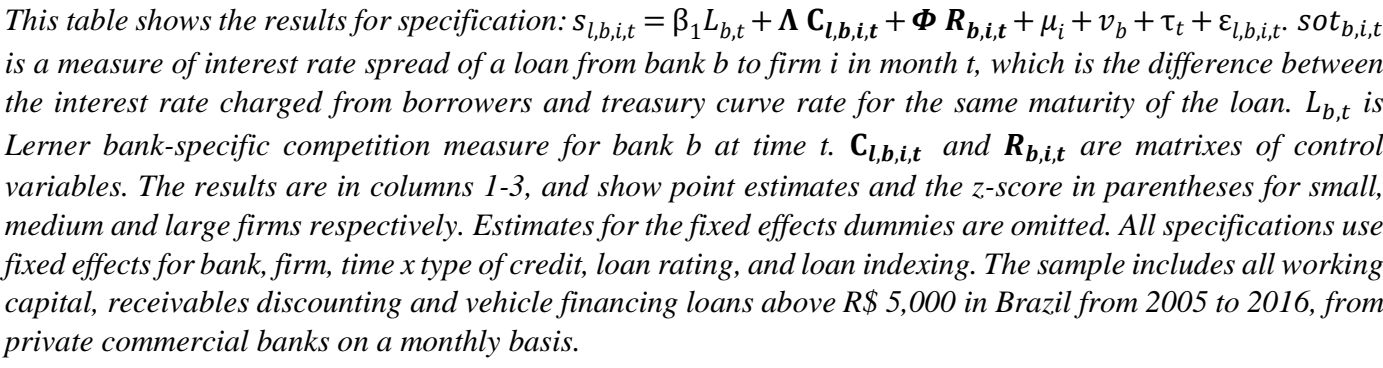 } \\
\hline
\end{tabular}

\subsection{Spreads and Bank-Firm Relationship}

In this subsection, we get a closer look at the bank-firm relationship. As seen before, the spread of private banks has a positive coefficient with the duration of the bankfirm relationship, and the number of accounts of the firm has some puzzling results. We go deep into this issue by creating dummies for the relationship duration and the number of accounts, as well as analyzing these issues also for state-owned banks.

We modify our baseline specification, changing the relationship duration and number of accounts by dummy variables. For the relationship duration, we create dummies for durations between one and two years, between two and four years, and above four years. The base-case dummy is duration below one year. For the number of accounts 
of a firm, we have dummies for two accounts, three accounts, and four or more accounts.Table VIII shows the results for private banks and Table IX for state-owned banks. For private banks, we see that spreads monotonically increase with the relationship duration. The use of dummies facilitates the interpretation of the relationship duration. Firms in the second year of the relationship with the bank pay between 22 and 38 basis points more than those in the first year, depending on the specification. This estimate increases to the range 47-55 for relationships of the $3^{\text {rd }}$ or $4^{\text {th }}$ year. For relations beyond the $5^{\text {th }}$ year, the increase against the first year is between 65 and 84 basis points. All coefficients are statistically significant at $1 \%$.

On the other hand, results for state-owned banks in Table IX show negative coefficients for the relationship duration dummies. Relationship duration coefficients are negative for the second year and become even more negative in the third and fourth years. From the fifth year and beyond it recovers to a level between the first and second years (coefficients are between -17 and -29 basis points). A possible interpretation is that stateowned banks use the information to reduce spreads up to a certain point, and then, after four years, increase spreads. We can conclude that private and public banks have different behavior when dealing with firms' relationships.

Regarding the number of accounts results for private banks (Table VIII) we uncover interesting results using dummy variables. In column 1, although all number of accounts dummies are positive, only the dummy for 4 or more accounts is positive and statistically significant. In column 5 , which is the same specification of column 1 , but with the set of observations of column 4, we have no more statistically significant coefficients, and point estimates are sometimes negative. The observations that are excluded from columns 1 and 5 are those from firms with one loan per year. Thus, there is evidence that the positive coefficient in column 1 of Table II is driven by a particular type of firm, namely those with many accounts and few loans. 
Table VIII - Spreads, Lerner Index and Dummy Relationship Variables - Private Banks

\begin{tabular}{|c|c|c|c|c|c|}
\hline & $\begin{array}{c}(1) \\
\text { Spread }\end{array}$ & $\begin{array}{c}(2) \\
\text { Spread }\end{array}$ & $\begin{array}{c}(3) \\
\text { Spread }\end{array}$ & $\begin{array}{c}(4) \\
\text { Spread }\end{array}$ & $\begin{array}{c}(5) \\
\text { Spread }\end{array}$ \\
\hline Lerner (Bank Level) & $\begin{array}{l}0.0068^{* * *} \\
\quad(6.30)\end{array}$ & $\begin{array}{l}0.0052 * * * \\
(5.48)\end{array}$ & $\begin{array}{l}0.0023 * * \\
(2.24)\end{array}$ & $\begin{array}{l}0.0020^{* *} \\
(2.08)\end{array}$ & $\begin{array}{l}0.0068 * * * \\
(6.25)\end{array}$ \\
\hline Relationship: $2^{\text {nd }}$ year & $\begin{array}{l}0.3854 * * * \\
\quad(7.92)\end{array}$ & $\begin{array}{l}0.3373 * * * \\
\quad(8.09)\end{array}$ & $\begin{array}{l}0.3882 * * * \\
\quad(9.65)\end{array}$ & $\begin{array}{l}0.2208 * * * \\
\quad(7.08)\end{array}$ & $\begin{array}{l}0.3312 * * * \\
\quad(7.04)\end{array}$ \\
\hline $\begin{array}{l}\text { Relationship: } 3^{\text {rd }} \text { and } 4^{\text {th }} \\
\text { year }\end{array}$ & $\begin{array}{l}0.5281 * * * \\
\quad(9.36)\end{array}$ & $\begin{array}{l}0.5546^{* * * *} \\
(10.56)\end{array}$ & $\begin{array}{l}0.5444 * * * \\
(13.91)\end{array}$ & $\begin{array}{l}0.4664 * * * \\
\quad(11.41)\end{array}$ & $\begin{array}{l}0.4953 * * * \\
\quad(8.47)\end{array}$ \\
\hline $\begin{array}{l}\text { Relationship: } 5^{\text {th }} \text { and } \\
\text { beyond }\end{array}$ & $\begin{array}{l}0.6829 * * * \\
\quad(9.77)\end{array}$ & $\begin{array}{l}0.8376^{* * * *} \\
\quad(14.12)\end{array}$ & $\begin{array}{l}0.7254 * * * \\
(13.98)\end{array}$ & $\begin{array}{l}0.7262 * * * \\
(14.42)\end{array}$ & $\begin{array}{l}0.6453 * * * \\
\quad(8.77)\end{array}$ \\
\hline \# Accounts: 2 & $\begin{array}{c}0.0078 \\
(0.28)\end{array}$ & $\begin{array}{c}-0.2236 * * * \\
(-5.65)\end{array}$ & $\begin{array}{c}-0.0519 * * \\
(-2.11)\end{array}$ & $\begin{array}{c}-0.2328 * * * \\
(-5.97)\end{array}$ & $\begin{array}{l}-0.0173 \\
(-0.58)\end{array}$ \\
\hline \# Accounts: 3 & $\begin{array}{c}0.0196 \\
(0.49)\end{array}$ & $\begin{array}{c}-0.3821 * * * \\
(-7.16)\end{array}$ & $\begin{array}{c}-0.0931 * * * \\
(-2.85)\end{array}$ & $\begin{array}{c}-0.3944 * * * \\
(-7.49)\end{array}$ & $\begin{array}{c}-0.0479 \\
(-1.19)\end{array}$ \\
\hline \# Accounts: $>=4$ & $\begin{array}{c}0.1288 * * \\
(2.43)\end{array}$ & $\begin{array}{c}-0.5220 * * * \\
(-8.13)\end{array}$ & $\begin{array}{c}0.0210 \\
(0.50)\end{array}$ & $\begin{array}{c}-0.5302 * * * \\
(-8.40)\end{array}$ & $\begin{array}{c}0.0118 \\
(0.23)\end{array}$ \\
\hline Log(Loan Amount) & $\begin{array}{c}-4.7716 * * * \\
(-44.56)\end{array}$ & $\begin{array}{c}-4.1722 * * * \\
(-40.93)\end{array}$ & $\begin{array}{c}-4.8255 * * * \\
(-45.28)\end{array}$ & $\begin{array}{c}-4.2009 * * * \\
(-41.20)\end{array}$ & $\begin{array}{c}-4.4549 * * * \\
(-44.93)\end{array}$ \\
\hline Collateral & $\begin{array}{c}-0.3769 * \\
(-1.78)\end{array}$ & $\begin{array}{c}-0.5432 * * * \\
(-2.71)\end{array}$ & $\begin{array}{c}-0.7720 * * * \\
(-4.00)\end{array}$ & $\begin{array}{c}-0.6019 * * * \\
(-3.05)\end{array}$ & $\begin{array}{c}-0.3844^{*} \\
(-1.83)\end{array}$ \\
\hline Loan Maturity & $\begin{array}{c}-0.2789 * * * \\
(-43.66)\end{array}$ & $\begin{array}{c}-0.3061 * * * \\
(-42.16)\end{array}$ & $\begin{array}{c}-0.2806 * * * \\
(-44.35)\end{array}$ & $\begin{array}{c}-0.3098 * * * \\
(-43.09)\end{array}$ & $\begin{array}{c}-0.2952 * * * \\
(-43.06)\end{array}$ \\
\hline Type of Institution & $\begin{array}{l}\text { Private } \\
\text { Banks }\end{array}$ & $\begin{array}{l}\text { Private } \\
\text { Banks }\end{array}$ & $\begin{array}{l}\text { Private } \\
\text { Banks }\end{array}$ & $\begin{array}{l}\text { Private } \\
\text { Banks }\end{array}$ & $\begin{array}{l}\text { Private } \\
\text { Banks }\end{array}$ \\
\hline $\begin{array}{l}\text { Adj } \mathrm{R}^{2} \\
\text { Fixed Effects }\end{array}$ & $\begin{array}{c}0.6362 \\
\text { Bank, Firm, } \\
\text { loan rating, } \\
\text { Month x } \\
\text { type of } \\
\text { credit, index } \\
\text { rate }\end{array}$ & $\begin{array}{c}0.7097 \\
\text { Bank, Firm x } \\
\text { Year, loan } \\
\text { rating, } \\
\text { Month x } \\
\text { type of } \\
\text { credit, index } \\
\text { rate }\end{array}$ & $\begin{array}{c}0.6459 \\
\text { Bank x Year, } \\
\text { Firm, loan } \\
\text { rating, } \\
\text { Month x } \\
\text { type of } \\
\text { credit, index } \\
\text { rate }\end{array}$ & $\begin{array}{c}0.7137 \\
\text { Bank x Year, } \\
\text { Firm x Year, } \\
\text { loan rating, } \\
\text { Month x } \\
\text { type of } \\
\text { credit, index } \\
\text { rate }\end{array}$ & $\begin{array}{c}0.6460 \\
\text { Bank, Firm, } \\
\text { loan rating, } \\
\text { Month x } \\
\text { type of } \\
\text { credit, index } \\
\text { rate }\end{array}$ \\
\hline \# Observations & $12,886,048$ & $10,735,123$ & $12,886,003$ & $10,735,074$ & $10,735,074$ \\
\hline $\begin{array}{l}\text { \# Bank FE } \\
\text { \# Firm FE }\end{array}$ & $\begin{array}{c}130 \\
1,371,266\end{array}$ & $\begin{array}{c}129 \\
2,306,489\end{array}$ & $\begin{array}{c}942 \\
1,371,263\end{array}$ & $\begin{array}{c}922 \\
2,306,478\end{array}$ & $\begin{array}{c}128 \\
1,011,870\end{array}$ \\
\hline \multicolumn{6}{|c|}{ 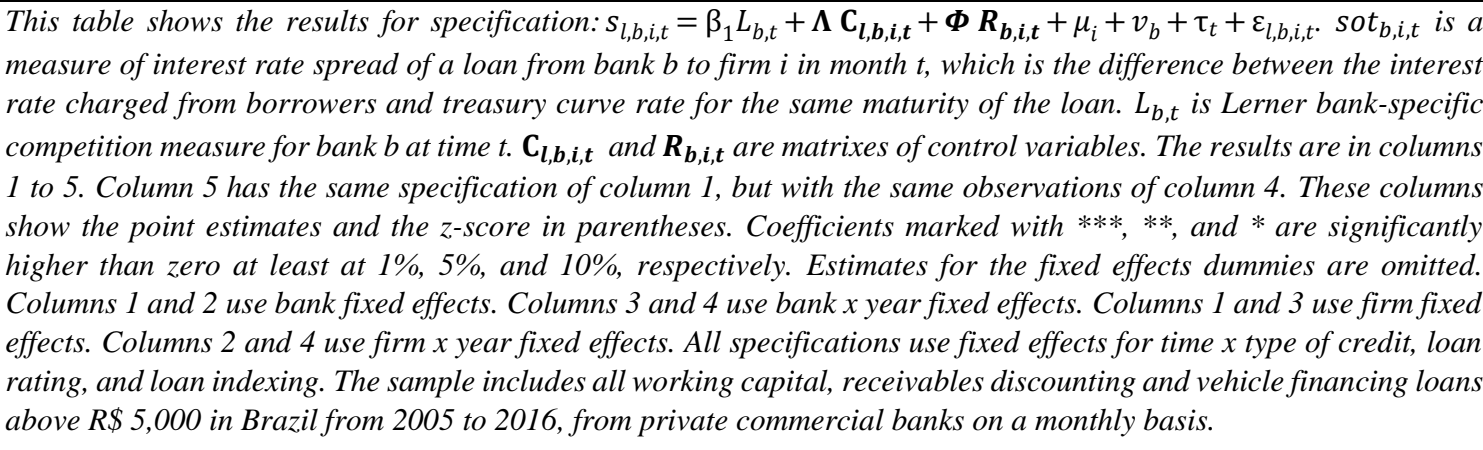 } \\
\hline
\end{tabular}


Table IX - Spreads, Lerner Index and Dummy Relationship Variables - StateOwned Banks

\begin{tabular}{|c|c|c|c|c|c|}
\hline & $\begin{array}{c}(1) \\
\text { Spread }\end{array}$ & $\begin{array}{c}(2) \\
\text { Spread }\end{array}$ & $\begin{array}{c}(3) \\
\text { Spread }\end{array}$ & $\begin{array}{c}(4) \\
\text { Spread }\end{array}$ & $\begin{array}{c}(5) \\
\text { Spread } \\
\end{array}$ \\
\hline Lerner (Bank Level) & $\begin{array}{l}0.3649 \\
(0.49)\end{array}$ & $\begin{array}{c}0.7779 \\
(1.23)\end{array}$ & $\begin{array}{l}0.8943 \\
(1.45)\end{array}$ & $\begin{array}{l}1.0177 \\
(1.61)\end{array}$ & $\begin{array}{c}0.3552 \\
(0.44)\end{array}$ \\
\hline Relationship: $2^{\text {nd }}$ year & $\begin{array}{c}-0.3666^{* * *} \\
(-4.69)\end{array}$ & $\begin{array}{c}-0.2199 * * * \\
(-2.93)\end{array}$ & $\begin{array}{c}-0.4087 * * * \\
(-5.27)\end{array}$ & $\begin{array}{c}-0.2570 * * * \\
(-3.42)\end{array}$ & $\begin{array}{c}-0.2458 * * * \\
(-3.48)\end{array}$ \\
\hline $\begin{array}{l}\text { Relationship: } 3^{\text {rd }} \text { and } 4^{\text {th }} \\
\text { year }\end{array}$ & $\begin{array}{c}-0.4350 * * * \\
(-4.29)\end{array}$ & $\begin{array}{c}-0.2285^{* *} \\
(-2.26)\end{array}$ & $\begin{array}{c}-0.4819 * * * \\
(-4.81)\end{array}$ & $\begin{array}{c}-0.2773 * * * \\
(-2.70)\end{array}$ & $\begin{array}{c}-0.3284 * * * \\
(-3.21)\end{array}$ \\
\hline Relationship: $5^{\text {th }}$ and beyond & $\begin{array}{c}-0.2588^{* *} \\
(-2.56)\end{array}$ & $\begin{array}{c}-0.1731 * \\
(-1.80)\end{array}$ & $\begin{array}{c}-0.2893 * * * \\
(-2.93)\end{array}$ & $\begin{array}{c}-0.1959 * * \\
(-1.99)\end{array}$ & $\begin{array}{c}-0.1975^{*} \\
(-1.82)\end{array}$ \\
\hline \# Accounts: 2 & $\begin{array}{c}-0.2187 * * * \\
(-7.10)\end{array}$ & $\begin{array}{c}-0.2064 * * * \\
(-5.50)\end{array}$ & $\begin{array}{c}-0.2196 * * * \\
(-8.42)\end{array}$ & $\begin{array}{c}-0.2003 * * * \\
(-5.42)\end{array}$ & $\begin{array}{c}-0.2161 * * * \\
(-7.83)\end{array}$ \\
\hline \# Accounts: 3 & $\begin{array}{c}-0.4243 * * * \\
(-9.49)\end{array}$ & $\begin{array}{c}-0.3283 * * * \\
(-6.33)\end{array}$ & $\begin{array}{c}-0.4105 * * * \\
(-10.77)\end{array}$ & $\begin{array}{c}-0.3211 * * * \\
(-6.33)\end{array}$ & $\begin{array}{c}-0.4235 * * * \\
(-10.73)\end{array}$ \\
\hline \# Accounts: $>4$ & $\begin{array}{c}-0.6411 * * * \\
(-11.75)\end{array}$ & $\begin{array}{c}-0.3968 * * * \\
(-6.04)\end{array}$ & $\begin{array}{c}-0.6192 * * * \\
(-13.60)\end{array}$ & $\begin{array}{c}-0.3861 * * * \\
(-6.04)\end{array}$ & $\begin{array}{c}-0.6082 * * * \\
(-12.67)\end{array}$ \\
\hline $\log ($ Loan Amount $)$ & $\begin{array}{c}-0.9978 * * * \\
(-18.56)\end{array}$ & $\begin{array}{c}-0.6845 * * * \\
(-12.55)\end{array}$ & $\begin{array}{c}-0.9806 * * * \\
(-18.55)\end{array}$ & $\begin{array}{c}-0.6780 * * * \\
(-12.48)\end{array}$ & $\begin{array}{c}-0.9036 * * * \\
(-15.95)\end{array}$ \\
\hline Collateral & $\begin{array}{c}0.3072 * * \\
(2.52)\end{array}$ & $\begin{array}{c}0.3918 * * * \\
(3.41)\end{array}$ & $\begin{array}{c}0.3877 * * * \\
\quad(3.39)\end{array}$ & $\begin{array}{c}0.3679 * * * \\
(3.15)\end{array}$ & $\begin{array}{l}0.5901^{* * * *} \\
\quad(4.85)\end{array}$ \\
\hline Loan Maturity & $\begin{array}{c}0.0276^{* * *} \\
(2.45)\end{array}$ & $\begin{array}{c}0.0267 * * \\
(2.22)\end{array}$ & $\begin{array}{c}0.0295 * * \\
(2.55) \\
\end{array}$ & $\begin{array}{c}0.0279 * * \\
(2.29)\end{array}$ & $\begin{array}{c}0.0223 * * \\
(2.07)\end{array}$ \\
\hline $\operatorname{Adj} R^{2}$ & $\begin{array}{c}\text { State- } \\
\text { Owned } \\
\text { Banks } \\
0.6690\end{array}$ & $\begin{array}{c}\text { State- } \\
\text { Owned } \\
\text { Banks } \\
0.7809\end{array}$ & $\begin{array}{c}\text { State- } \\
\text { Owned } \\
\text { Banks } \\
0.6769\end{array}$ & $\begin{array}{c}\text { State- } \\
\text { Owned } \\
\text { Banks } \\
0.7827\end{array}$ & $\begin{array}{c}\text { State- } \\
\text { Owned } \\
\text { Banks } \\
0.6904\end{array}$ \\
\hline Fixed Effects & $\begin{array}{l}\text { Bank, Firm, } \\
\text { loan rating, } \\
\text { Month x } \\
\text { type of } \\
\text { credit, index } \\
\text { rate }\end{array}$ & $\begin{array}{l}\text { Bank, Firm } \\
\text { x Year, loan } \\
\text { rating, } \\
\text { Month x } \\
\text { type of } \\
\text { credit, index } \\
\text { rate }\end{array}$ & $\begin{array}{c}\text { Bank x } \\
\text { Year, Firm, } \\
\text { loan rating, } \\
\text { Month x } \\
\text { type of } \\
\text { credit, index } \\
\text { rate }\end{array}$ & $\begin{array}{c}\text { Bank x } \\
\text { Year, Firm x } \\
\text { Year, loan } \\
\text { rating, } \\
\text { Month x } \\
\text { type of } \\
\text { credit, index } \\
\text { rate }\end{array}$ & $\begin{array}{c}\text { Bank, Firm, } \\
\text { loan rating, } \\
\text { Month x } \\
\text { type of } \\
\text { credit, index } \\
\text { rate }\end{array}$ \\
\hline \# Observations & $5,882,056$ & $5,278,900$ & $5,882,056$ & $5,278,900$ & $5,278,900$ \\
\hline $\begin{array}{l}\text { \# Bank FE } \\
\text { \# Firm FE }\end{array}$ & 13 & 13 & 107 & 106 & 13 \\
\hline \multicolumn{6}{|c|}{ 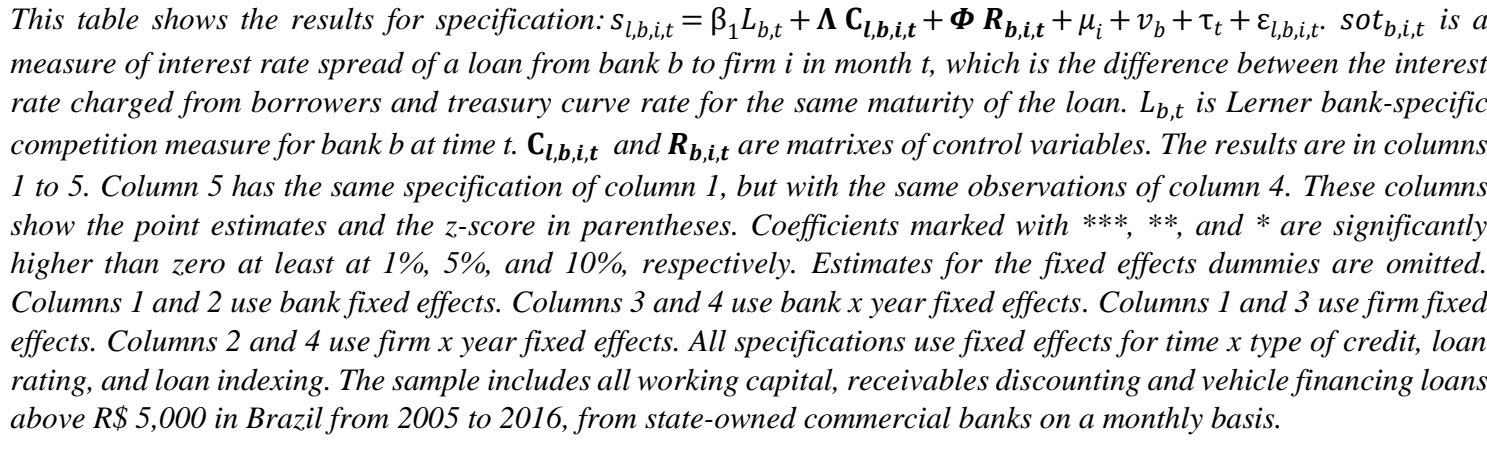 } \\
\hline
\end{tabular}


On the specifications with either Firm x Year or Bank x Year fixed effects, the coefficients from the number of accounts are mainly negative and statistically significant. Therefore, in general, the higher is the number of accounts, the lower is the spread from private banks, but with the exception of a particular type of firm.

For state-owned banks (Table IX), the coefficients for the number of accounts are negative and statistically significant. Furthermore, they become more negative as the number of accounts increase. Overall it seems that the higher the number of accounts is, the lower is the spread, and this effect is stronger for state-owned banks.

Table IX also shows that the bank-specific Lerner index considering state-owned banks has a positive, but not statistically significant coefficient. The sign of the collateral coefficient is positive, differently from private banks, and against intuition. ${ }^{16}$ Therefore, our empirical findings uncover several different behaviors between private and stateowned banks.

\section{Capture then Extract Rents?}

In this section, we study a strategy colloquially known as "bargain then rip-off", that Degryse et al. (2009, page 97) describes as "first competing fiercely for new customers and then charge above marginal cost prices". This kind of behavior is present in the model of Sharpe (1990) and is empirically analyzed using Bolivian data by Ioannidou and Ongena (2010). We first estimate how much the bank reduces the spread in order to "capture" the client (the "bargain" behavior). This is also associated with the notion of switching costs since the firm would change to a new bank if the spread offered by this bank is lower enough to compensate for the costs of switching. Later, we examine the "rip-off" or "extract rent" behavior by estimating how much the spread increases after the firm has been captured.

This bank behavior is another evidence of lack of competition that may go beyond what can be captured by the Lerner index.

\footnotetext{
${ }^{16} \mathrm{~A}$ possible explanation here is that the collateral variable is correlated with the type of loan: vehicles and receivables discounting are more likely to have collateral than working capital. Thus, we may have a problem of collinearity.
} 


\subsection{Capturing and Switching}

In this subsection, we consider the case in which a firm changes from one bank to another in order to evaluate the switching costs, or how much a private bank is willing to reduce its spread to capture a new client. As in Ioannidou and Ongena (2010), our main interest is when a firm switches to a bank with no previous relationship. In this way, the switching cost would be associated with information asymmetries, since the new bank would not have financial records from the firm. This analysis uses the sample of private bank loans, i.e., when the firm switches to a private bank. Loans from other types of institutions are used only to check whether the previous loan of the firm is from another bank, i.e., whether the firm is switching.

In order to address the information issue, we build our main switching variable $S \boldsymbol{W}$ combining bank switching and relationship duration, in the following five cases:

- Renewal with old relationship: the previous loan of the firm was with the same bank and the relationship with the bank started more than one year ago. This is our base-case dummy value with $41.3 \%$ of observations;

- Switch to a new bank: the previous loan of the firm was with a different bank, and the relationship with the current bank started less than one year ago. Therefore, the firm is switching to a bank with no previous relationship. This case has $9.9 \%$ of the observations;

- Switch to an old relationship: the previous loan of the firm was with a different bank, and the relationship with the current bank started more than one year ago. Therefore, the firm is switching to a bank with an existing relationship. This case has $21.5 \%$ of the observations;

- Renewal with a new relationship: the previous loan of the firm was with the same bank, and the relationship with the bank started less than one year ago. This case has $12.7 \%$ of the observations.

- First loan in the sample: This is the first loan of the firm in our sample, but not necessarily the first loan of the firm. This case has $14.6 \%$ of the observations.

The unconditional mean spread for the renewal with an old relationship is 25.99 percentage points for private banks, while the switch to new bank loans has a mean spread of 21.68 percentage points so that we have evidence of switching costs associated with information asymmetries. We further analyze this issue using the following regression: 


$$
s_{l, b, i, t}=\alpha \mathbf{S W}_{l, i}+\boldsymbol{\Phi} \mathbf{R}_{b, i, t}+\mu_{i}+v_{b}+\tau_{t}+\varepsilon_{l, b, i, t},
$$

where:

$\mathbf{S W}_{l, i}$ is a set of dummy variables with the switching status of the loan, as described above. The possible values are the following: Renewal with an old relationship (base-case dummy value); switch to a new bank; switch to an old relationship; renewal with a new relationship; and first loan in the sample.

Loans from firms switching to a private bank with no previous relationship are associated with a spread around half percentage point lower than renewing with the current bank where the firm has an old relationship, which is our base case value for the dummy. If the switch is to a bank with an existing relationship, the spread is 21 basis points higher. Therefore, switching costs seem to be associated with information asymmetry since switch coefficient is negative for firms with recent bank relationships and positive for firms with longer relationships.

Renewing with a bank with a recent relationship is also associated with lower spreads, even lower than that resulting from switching to a new bank. The estimated coefficient associated with the first loan of the sample (not necessarily the first loan of the firm) is almost -0.6 percentage point, consistent with results of the previous section.

When we consider the results by firm size in columns 2 to 4 , the switching to a new relationship has coefficients ranging from -0.41 percentage point for medium and large firms to -1.05 percentage points for micro firms.

Another interesting issue for the Brazilian market is whether the private bank is capturing the client from another private bank or from a state-owned bank. Figure III shows switching costs by firm size and by the type of the previous financial institution. In this way, the switching to a new bank variable is decomposed into four different types depending on the previous financial institutions: private banks, public banks, credit unions, and other institutions. For each type, we consider three firm sizes. 
Table X - Switching

\begin{tabular}{|c|c|c|c|c|}
\hline & $\begin{array}{c}(1) \\
\text { Spread } \\
\text { All Firm Sizes } \\
\end{array}$ & $\begin{array}{c}(2) \\
\text { Spread } \\
\text { Micro Firms }\end{array}$ & $\begin{array}{c}(3) \\
\text { Spread } \\
\text { Small Firms }\end{array}$ & $\begin{array}{c}\text { (4) } \\
\text { Spread } \\
\text { Mid-Large Firms }\end{array}$ \\
\hline Lerner (Bank Level) & $\begin{array}{c}0.0064 * * * \\
(5.94)\end{array}$ & $\begin{array}{c}0.0116^{* * *} \\
(3.39)\end{array}$ & $\begin{array}{c}0.0072 * * * \\
(4.60)\end{array}$ & $\begin{array}{c}0.0036^{* * * *} \\
(3.39)\end{array}$ \\
\hline Log (Loan Amount) & $\begin{array}{c}-4.7158 * * * \\
(-35.80)\end{array}$ & $\begin{array}{c}-5.6641 * * * \\
(-19.80)\end{array}$ & $\begin{array}{c}-5.8530 * * * \\
(-32.70)\end{array}$ & $\begin{array}{c}-2.6366^{* * *} \\
(-25.48)\end{array}$ \\
\hline Collateral & $\begin{array}{l}0.0053 \\
(0.03)\end{array}$ & $\begin{array}{c}-0.7601 * * * \\
(-3.12)\end{array}$ & $\begin{array}{c}-0.3702 \\
(-1.30)\end{array}$ & $\begin{array}{l}0.0567 \\
(0.48)\end{array}$ \\
\hline Loan Maturity & $\begin{array}{c}-0.2789 * * * \\
(-37.24)\end{array}$ & $\begin{array}{c}-0.2846 * * * \\
(-26.35)\end{array}$ & $\begin{array}{c}-0.3080 * * * \\
(-38.45)\end{array}$ & $\begin{array}{c}-0.1834 * * * \\
(-25.33)\end{array}$ \\
\hline $\begin{array}{l}\text { Switch (new } \\
\text { relationship) }\end{array}$ & $\begin{array}{c}-0.4974 * * * \\
(-9.11)\end{array}$ & $\begin{array}{c}-1.0520 * * * \\
(-12.82)\end{array}$ & $\begin{array}{c}-0.6039 * * * \\
(-9.21)\end{array}$ & $\begin{array}{c}-0.4103 * * * \\
(-7.18)\end{array}$ \\
\hline $\begin{array}{l}\text { Switch (old } \\
\text { relationship) }\end{array}$ & $\begin{array}{c}0.2107 * * * \\
(5.18)\end{array}$ & $\begin{array}{c}-0.0493 \\
(-0.73)\end{array}$ & $\begin{array}{c}0.1307 * * \\
(2.38)\end{array}$ & $\begin{array}{c}0.0911 * * * \\
(3.82)\end{array}$ \\
\hline First loan of the sample & $\begin{array}{c}-0.5943 * * * \\
(-9.57)\end{array}$ & $\begin{array}{c}-1.6091 * * * \\
(-12.87)\end{array}$ & $\begin{array}{c}-0.9273 * * * \\
(-13.10)\end{array}$ & $\begin{array}{c}-0.3657 * * * \\
(-5.43)\end{array}$ \\
\hline $\begin{array}{l}\text { Renewal (new } \\
\text { relationship) }\end{array}$ & $\begin{array}{c}-0.6108 * * * \\
(-10.19) \\
\end{array}$ & $\begin{array}{c}-0.7416 * * * \\
(-7.87)\end{array}$ & $\begin{array}{c}-0.6536^{* * *} \\
(-10.62) \\
\end{array}$ & $\begin{array}{c}-0.5188 * * * \\
(-10.06)\end{array}$ \\
\hline Type of Institution & $\begin{array}{l}\text { Switching to } \\
\text { Private Banks }\end{array}$ & $\begin{array}{l}\text { Switching to } \\
\text { Private Banks }\end{array}$ & $\begin{array}{l}\text { Switching to } \\
\text { Private Banks }\end{array}$ & $\begin{array}{l}\text { Switching to } \\
\text { Private Banks }\end{array}$ \\
\hline Adj $R^{2}$ & 0.6334 & 0.6820 & 0.6124 & 0.5672 \\
\hline Fixed Effects & $\begin{array}{l}\text { Bank, Firm, loan } \\
\text { rating, Month x } \\
\text { type of credit, } \\
\text { index rate }\end{array}$ & $\begin{array}{l}\text { Bank, Firm, loan } \\
\text { rating, Month x } \\
\text { type of credit, } \\
\text { index rate }\end{array}$ & $\begin{array}{l}\text { Bank, Firm, loan } \\
\text { rating, Month x } \\
\text { type of credit, } \\
\text { index rate }\end{array}$ & $\begin{array}{l}\text { Bank, Firm, loan } \\
\text { rating, Month x } \\
\text { type of credit, } \\
\text { index rate }\end{array}$ \\
\hline \# Observations & $9,006,115$ & $1,276,562$ & $4,629,473$ & $2,688,019$ \\
\hline \# Bank FE & 128 & 101 & 111 & 124 \\
\hline \# Firm FE & $1,122,310$ & 387,832 & 700,957 & 198,117 \\
\hline
\end{tabular}

This table shows the results for specification: $s_{l, b, i, t}=\alpha \mathrm{SW}_{l, i}+\mathbf{\Phi} \mathbf{R}_{\boldsymbol{b}, i, t}+\mu_{i}+v_{b}+\tau_{t}+\varepsilon_{l, b, i, t} \cdot s_{b, i, t}$ is a measure of interest rate spread of a loan from bank $b$ to firm $i$ in month $t$, which is the difference between the interest rate charged from borrowers and treasury curve rate for the same maturity of the loan. $\boldsymbol{R}_{\boldsymbol{b}, \boldsymbol{i}, \boldsymbol{t}}$ is a matrix of control variables. $\mathbf{S W}_{l, i}$ is a set of dummy variables with the switching status of the loan, whose values are: Renewal with old relationship (base-case dummy value); Switch to new bank; Switch to old relationship; Renewal with new relationship; and First loan in the sample. Loans are from private banks. Column 1 shows results for all firm sizes. Columns 2 to 4 show results for micro, small, and medium and large firms, respectively. Point estimates and the z-score are shown in parentheses. Coefficients marked with ***, **, and * are significantly higher than zero at least at 1\%, 5\%, and 10\%, respectively. All specifications use fixed effects for bank, firm, time x type of credit, loan rating, and loan indexing. The sample includes all working capital, receivables discounting and vehicle financing loans above $R \$ 5,000$ in Brazil from 2005 to 2016, from commercial banks on a monthly basis. 
Figure III - Switching to a New Private Bank

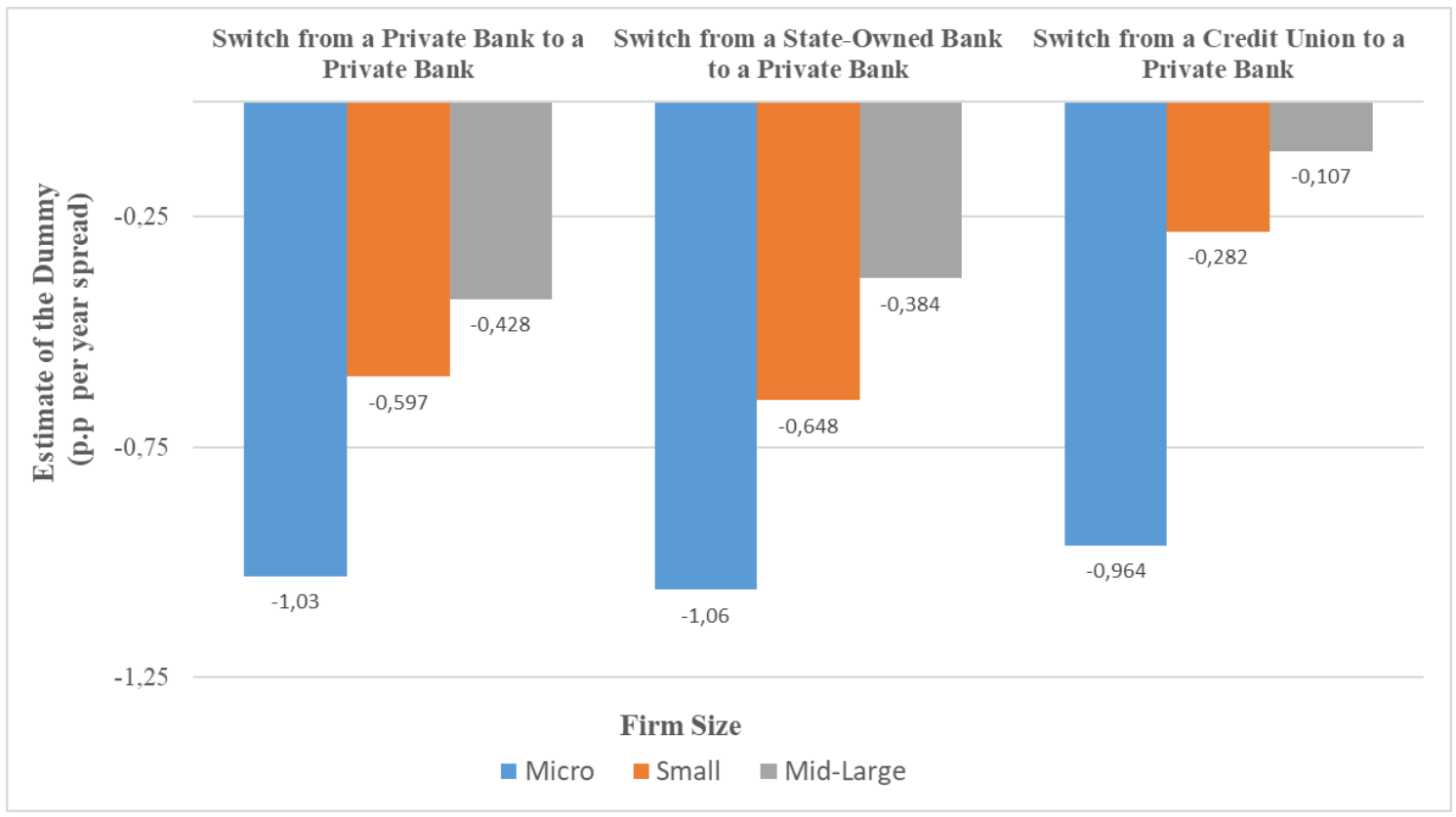

For micro firms, there is little difference whether the private bank is capturing a client from another private bank, from a state-owned bank or a credit union. In all these cases, the switching cost is around one percentage point. For small, medium and large firms, there is also little difference between private and state-owned banks, but switching costs from credit unions are smaller. Therefore, the type of the previous bank is not relevant, except for the case where the previous institution is a credit union and the firm is not micro.

If the same analysis is done for the case when state-owned banks are receiving clients from other banks, the switch to a new relationship variable is no longer negative. On the contrary, this coefficient is positive (not reported), indicating that public banks behave differently.

\subsection{Extracting Rents after the First Loan}

In the previous subsection, we found that private banks use to offer lower spreads to capture clients from other institutions. We now focus on the "extracting rents" phase of the strategy.

We compare the spread charged by banks in the first loan with those clients, and subsequent spreads if the relationship with them continues. In this section, we do not require that the firm is changing from another bank, so even a firm that is taking its first loan in the financial system is included. We evaluate the specific case of switching from 
another bank in the next section. We keep in this sub-sample only observations where the bank-firm relationships started after 2005, i.e., when the first loan of a bank-firm pair in our sample occurs in the first year of the bank-firm relationship. ${ }^{17}$

We use dummy variables with the position of the loan as an ordinal number:

$$
s_{l, b, i, t}=\alpha \mathbf{P}_{l, b, i}+\Lambda \mathbf{C}_{l, b, i, t}+\mathbf{\Phi} \mathbf{R}_{b, i, t}+\mu_{i}+v_{b}+\tau_{t}+\varepsilon_{l, b, i, t},
$$

where $\mathbf{P}_{l, b, \boldsymbol{i}}$ is a set of dummy variables for the ordinal position of the loan $l$ in the relationship between bank $b$ and firm $i$. The base-case dummy is the first loan, and we include dummies up to the $50^{\text {th }}$ loan.

Figure IV shows the estimates for each position dummy up to the $30^{\text {th }}$, considering only the private bank sample. All dummies estimates are statistically different from the first loan, except the dummy for the second loan. These dummies have monotonically increasing values up to the $15^{\text {th }}$ loan, where the estimate reaches one percentage point. After that, there is still an upward trend, although with some noise. The estimate keeps increasing, and the dummy for the $50^{\text {th }}$ loan has a value of 1.73 percentage points (not shown in the figure). The increasing pace of spreads seems to more than compensate for the initially lower spread documented in the previous section. The same analysis is done for state-owned banks and is shown in Figure V. We can see the spread decreasing until around the $20^{\text {th }}$ loan, reaching a level two percentage points lower than the first loan. After platooning from the $20^{\text {th }}$ to the $38^{\text {th }}$ loan, spreads invert the trend and increase about 20 basis points in the $50^{\text {th }}$ loan. We can have a similar interpretation as in the case of the relationship duration: state-owned banks use the information to reduce spreads up to a certain point, and then, after around the $40^{\text {th }}$ loan, start to increase spreads, although in a much smaller magnitude.

Overall, empirical evidence in this subsection supports the "bargain then rip-off" behavior by private banks in Brazil, suggesting that competition environment could be strengthened if barriers to information sharing are removed. This evidence is against the Information Hypothesis.

\footnotetext{
${ }^{17}$ We cannot just use the first loan in the sample since we do not have information before 2005, so we cannot assure this is the first loan overall.
} 
Figure IV - Ordinal Position and Spreads - Private Banks

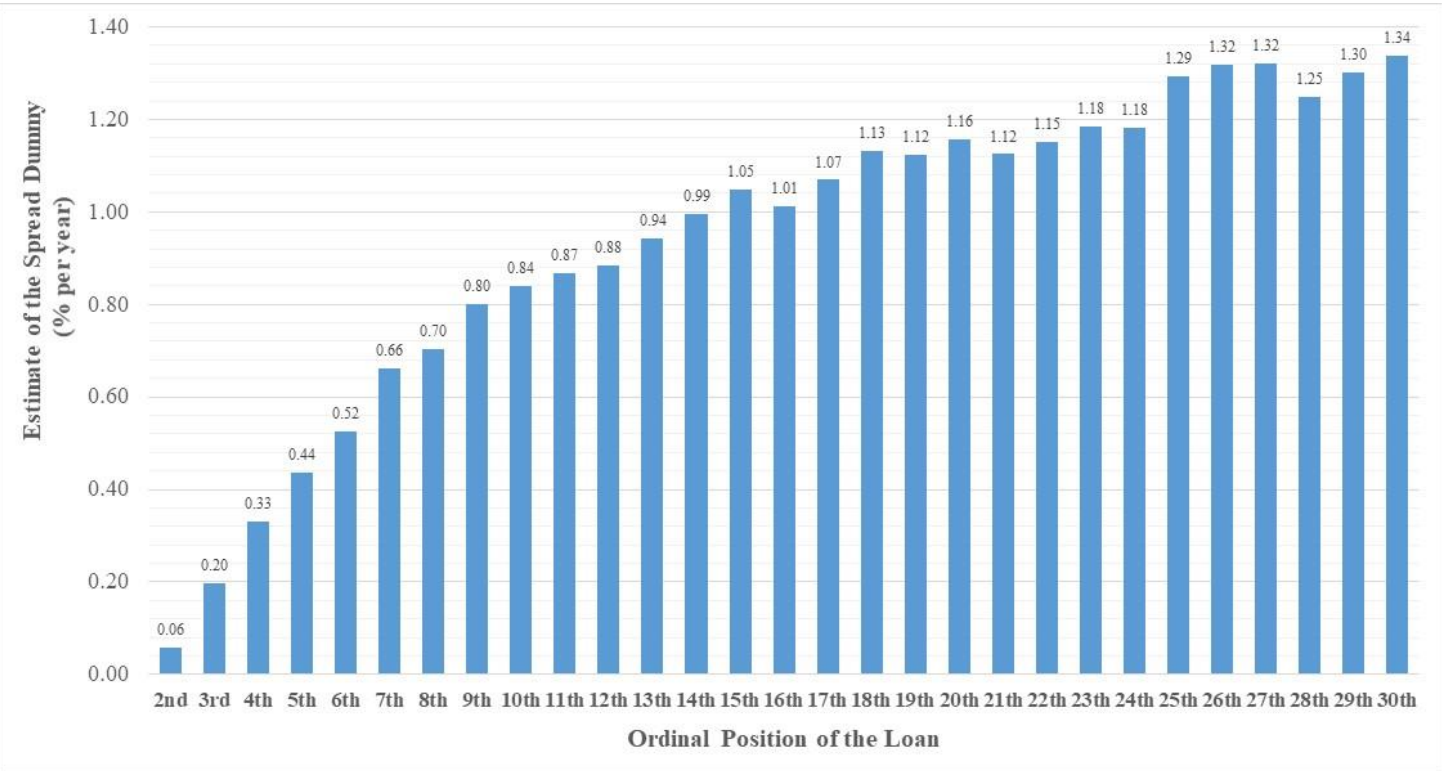

Figure V - Ordinal Position and Spreads - State-Owned Banks

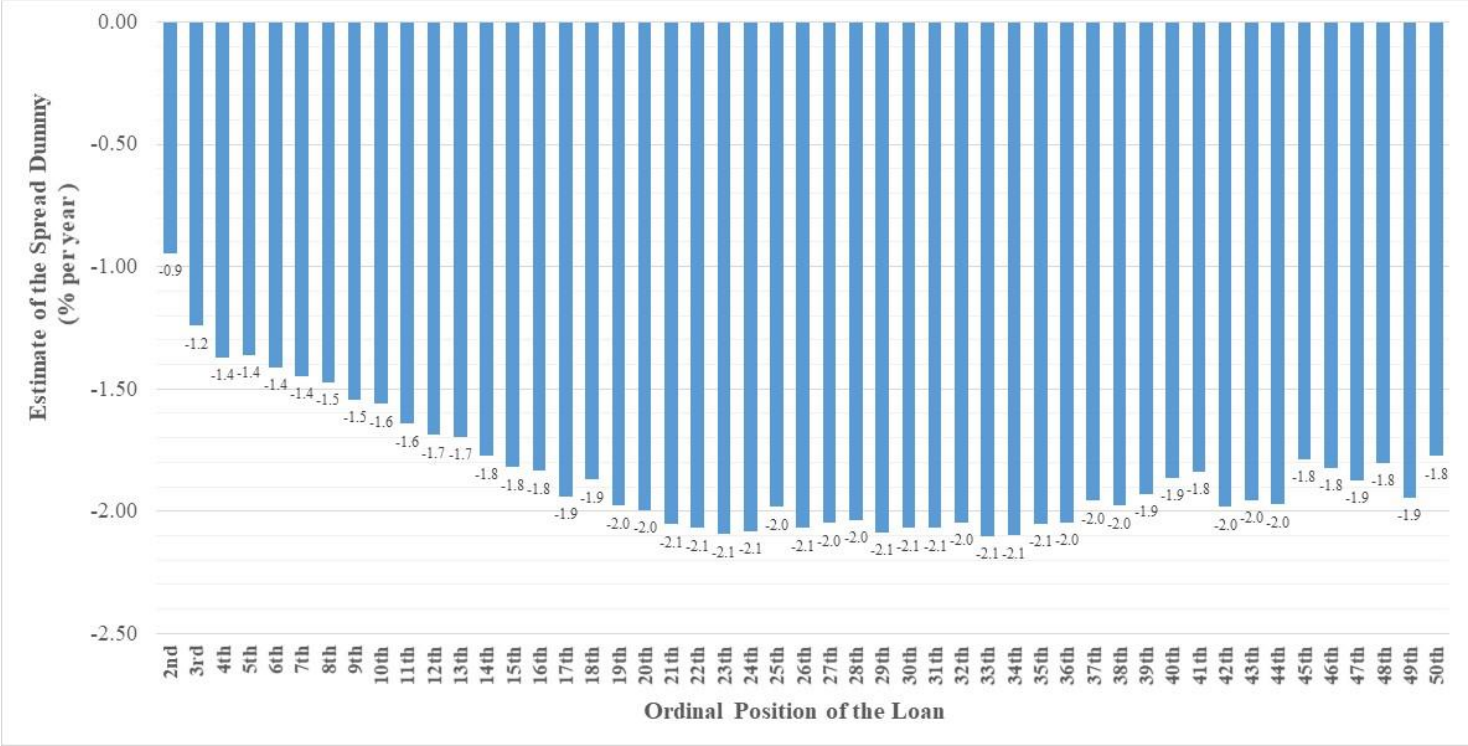

\subsection{Extracting Rents after a Switch}

In this subsection, we consider the case of loans granted after switching to a new private bank and check the "extracting rents" behavior in these cases. Figure VI shows the equivalent to Figure IV, but only for loans after a switch to a new relationship and differentiating by firm size. We see the same increasing spread behavior for all firm sizes. In order to compare these results with the switching costs, we add in this figure a horizontal line with the coefficient estimate of the "Swtich to a new relationship" of Table $\mathrm{X}$, but without the negative sign. In this comparison, we see that the initially lower spreads are subsequently compensated, and by the $3^{\text {rd }}$ loan the break-even is achieved for all firm 
sizes. By the $3^{\text {rd }}$ loan, a micro firm has a spread 1.10 percentage points higher than the first, which is higher than the switching to a new relationship cost of 1.05 for micro firms in Table X. After the $18^{\text {th }}$ loan, a micro firm pays a spread 4 to 4.5 percentage points higher than the first one, so that the bank is largely compensating the initial bargain effort.

Overall, we find evidence of extracting rents behavior by private banks both after a switch and after the first loan of the bank-firm relationship. Combined with the switching costs analysis, we find empirical support for the behavior of first capturing and then extracting rents by private banks in Brazil. Moreover, this capture seems linked to the informational content that banks acquire in the relationship with their clients. This situation can be seen as in a holdup problem setup, where the client's information is held by banks, which use it to extract rents.

\section{Figure VI - Ordinal Position and Spreads - After Switching to a Private Bank}

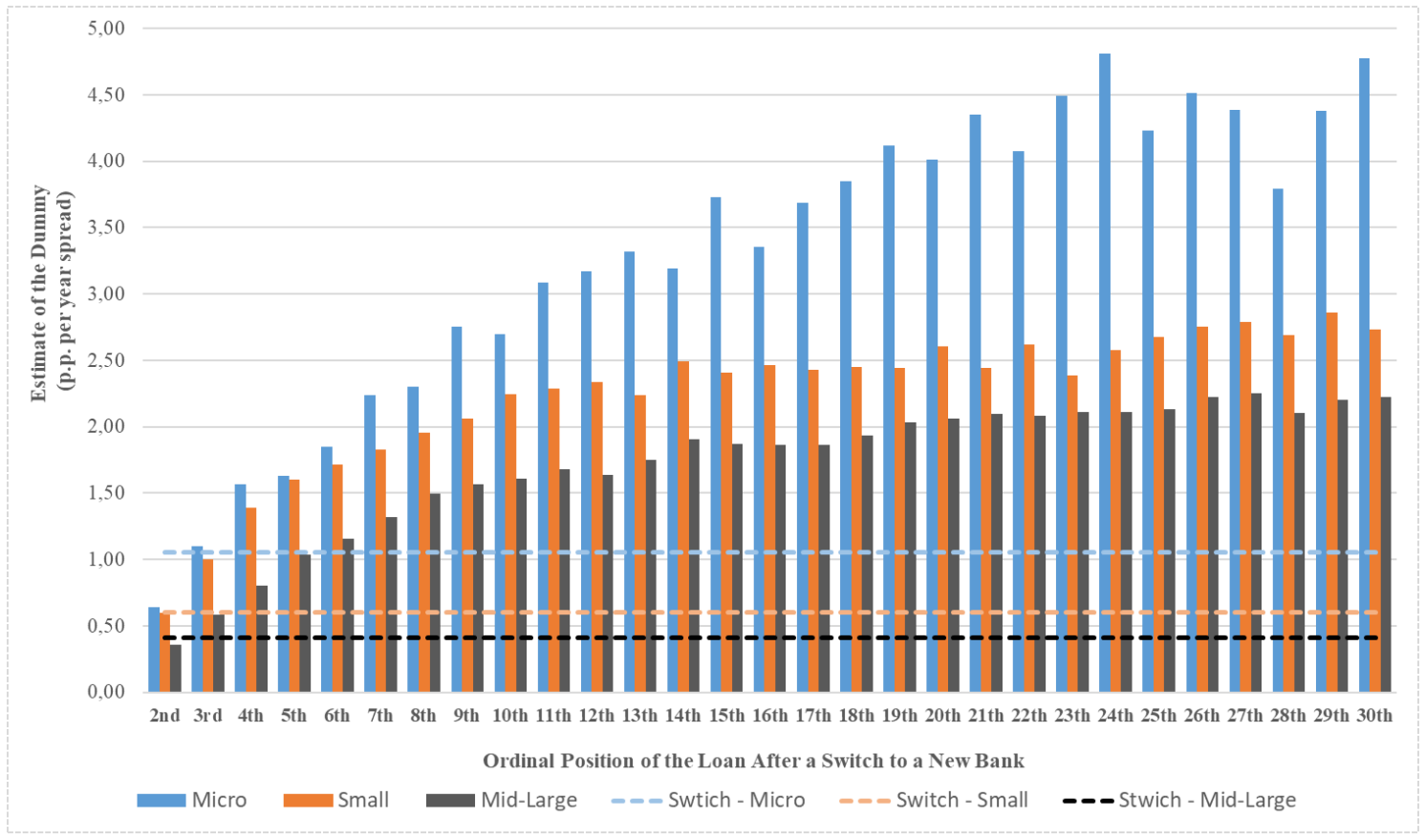

\section{Final Remarks}

This article provides evidence of how private bank's market power and the "capture then extract rents" behavior harm the competitive environment in Brazil and increase the cost of finance. We show empirical evidence of a direct relationship between market power (measured by the Lerner Index) and spreads for loans of private commercial banks. Furthermore, there is evidence that longer bank-firm relationships increase spreads. Therefore, our empirical evidence supports the market power hypothesis, but not 
the information hypothesis. Both results are stronger for micro and small firms than for medium and large firms.

This article also identifies the presence of the holdup problem in the Brazilian lending market. Private banks engage in a strategy of first capturing some of their clients by offering lower interest rates and then extracting rents, increasing interest rates as the relationship evolves. When firms switch to private banks with no previous relationship, they pay lower interest rates. This is evidence that informational switching costs are helping banks to hold firms as clients.

Given this diagnosis, policy responses related to foster information sharing may help to decrease switching costs and alleviate the holdup problem. Open banking initiatives can make information held by incumbent banks to flow towards other financial institutions so that firms can get better interest rates by outside banks, thus enhancing competition. Another policy initiative is to reduce entry barriers to new competitors, like the credit fintechs. These institutions usually have a transactional lending approach, instead of relationship banking, so that an open banking initiative can enhance their ability to obtain information about firms and provide better loan conditions. 


\section{References}

Bain, Joe S. (1951) Relation to profit rate to industry Concentration. Quarterly Journal of Economics, 65, pp. 293-324.

Berger, Allen N; Iftekhar, Hasan; Zhou, Mingming (2009) Bank ownership and efficiency in China: what will happen in the world's largest nation? Journal of Banking \& Finance 33, pp. 113-130.

Boone, Jan (2008) A new way to measure competition, Economic Journal, 118, pp. 12451261.

Carbo-Valverde, Santiago, Rodriguez-Fernandez, Francisco, Udell, Gregory F. (2009) Bank market power and SME financing constraints. Review of Finance 13 (2), pp. 309340.

Claessens, Stijn, and Luc Laeven (2004) What Drives Bank Competition? Some International Evidence. Journal of Money, Credit, and Banking 36, pp. 563-583.

Chong, Terence T. L., Lu, Liping, and Ongena, Steven (2013) Does banking competition alleviate or worsen credit constraints faced by small- and medium-sized enterprises? Evidence from China. Journal of Banking and Finance, 37(9), pp. 3412-3424.

Correia, Sergio (2017) reghdfe: Stata module for linear and instrumental-variable/gmm regression absorbing multiple levels of fixed effects. Statistical Software Components s457874, Boston College Department of Economics. https://ideas.repec.org/c/boc/bocode/s457874.html

Degryse, Hans, Kim, M. and Ongena, Steven (2009) Microeconometrics of Banking. Oxford: Oxford University Press.

Degryse, Hans and De Jonghe, Olivier and Jakovljević, Sanja and Mulier, Klaas and Schepens, Glenn (2019) Identifying Credit Supply Shocks with Bank-Firm Data: Methods and Applications. Journal of Financial Intermediation v. 40.

Freixas, Xavier and Rochet, Jean-Charles (2008) Microeconomics of Banking. Second Edition. The MIT Press.

Fungáčová, Zuzana, Anastasiya Shamshur and Laurent Weill (2017) Does bank competition reduce cost of credit? Cross-country evidence from Europe. Journal of Banking and Finance v. 83, pp. 104-120.

Gelos, R. Gaston (2009). Banking Spreads in Latin America. Economic Inquiry, vol. 47(4), pp. 796-814.

Ioannidou, Vasso and Ongena, Steven (2010) "Time for a Change": Loan Conditions and Bank Behavior when Firms Switch Banks. The Journal of Finance, Vol. 65, No. 5, pp. 1847-1877.

Jiménez, Gabriel, Ongena, Steven, Peydró, José-Luiz, and Saurina, Jesús (2014) Hazardous Times for Monetary Policy: What Do Twenty-Three Million Bank Loans Say About the Effects of Monetary Policy on Credit Risk-Taking? Econometrica, 82(2), pp. 463-505.

Klemperer, Paul (1995) Competition when Consumers have Switching Costs: An Overview with Applications to Industrial Organization, Macroeconomics, and International Trade. Review of Economic Studies 62, pp. 515-539. 
Kysucky, Vlado and Norden, Lars (2016) The benefits of relationship lending in a crosscountry context: a meta-analysis. Management Science 62 (1), pp. 90-110.

Martins, Bruno S. (2012) Local Market Structure and Bank Competition: evidence from the Brazilian auto loan market. Working Paper Series N. 299, Banco Central do Brasil.

Panzar, John C. and Rosse, James N. (1987) Testing for monopoly equilibrium. The Journal of Industrial Economics 35, No. 4, pp. 443-456.

Petersen, Mitchell A. and Rajan, Raghuram G. (1995). The Effect of Credit Market Competition on Lending Relationship. Quarterly Journal of Economics 110, pp. 407-443.

Ryan, Robert M., O’Toole, Conor M., and McCann, Fergal (2014) Does bank market power affect SME financing constraints? Journal of Banking and Finance, 49, pp. 495505 .

Sharpe, Steven A. (1990) Asymmetric Information, Bank Lending and Implicit Contracts: A Stylized Model of Customer Relationships. The Journal of Finance, Vol. 45, No. 4, pp. 1069-1087.

Silva, Guilherme J. C., and Pirtouscheg, Lívia A. S. (2015) Basic interest rate, bank competition and bank spread in personal credit operations in Brazil: A theoretical and empirical analysis. EconomiA, Volume 16, Issue 1, 2015, pp. 32-45.

Silva, Marcos Soares (2014) Avaliação do Processo de Concentração-Competição no Setor Bancário Brasileiro. Working Paper Series N. 377, Banco Central do Brasil.

Spierdijk, Laura and Michalis Zaouras (2017) The Lerner Index and Revenue Maximization. Applied Economics Letters Volume 24, Issue 15, pp. 1075-1079.

Van Leuvensteijn, Michael, Sørensen, Christoffer K., Bikker, Jacob A., Adrian A.R.J.M. van Rixtel (2013) Impact of bank competition on the interest rate pass-through in the Euro area, Applied Economics, 45, pp. 1359-1380.

Vervliet, Tobias (2015) The Lerner Index as a Measure of Market Power of U.S. Credit Unions in the Absence of Profit Maximization. Student Research Conference (SURE!), vol. 1. 


\section{Appendix I - Robustness Tests Tables}

Table XI - Lagged Bank-specific Lerner Index and Spreads

\begin{tabular}{|c|c|c|c|c|c|}
\hline & $\begin{array}{c}(1) \\
\text { Spread }\end{array}$ & $\begin{array}{c}(2) \\
\text { Spread }\end{array}$ & $\begin{array}{c}(3) \\
\text { Spread }\end{array}$ & $\begin{array}{c}(4) \\
\text { Spread }\end{array}$ & $\begin{array}{c}(5) \\
\text { Spread }\end{array}$ \\
\hline One-Quarter Lagged & $0.0067 * * *$ & $0.0052 * * *$ & $0.0020 * *$ & $0.0018 *$ & $0.0067 * * *$ \\
\hline Lerner Index & $(6.17)$ & $(5.47)$ & $(2.02)$ & $(1.90)$ & (6.19) \\
\hline Log(Loan Amount) & $\begin{array}{c}-4.7698 * * * \\
(-44.44)\end{array}$ & $\begin{array}{c}-4.1700 * * * \\
(-40.81)\end{array}$ & $\begin{array}{c}-4.8238 * * * \\
(-45.16)\end{array}$ & $\begin{array}{c}-4.1990 * * * \\
(-41.09)\end{array}$ & $\begin{array}{c}-4.4532 * * * \\
(-44.84)\end{array}$ \\
\hline Collateral & $\begin{array}{c}-0.3812^{*} \\
(-1.80)\end{array}$ & $\begin{array}{c}-0.5449 * * * \\
(-2.72)\end{array}$ & $\begin{array}{c}-0.7736 * * * \\
(-4.01)\end{array}$ & $\begin{array}{c}-0.6022 * * * \\
(-3.05)\end{array}$ & $\begin{array}{c}-0.3869 * \\
(-1.84)\end{array}$ \\
\hline Loan Maturity & $\begin{array}{c}-0.2798 * * * \\
(-43.65)\end{array}$ & $\begin{array}{c}-0.3064 * * * \\
(-42.04)\end{array}$ & $\begin{array}{c}-0.2815 * * * \\
(-44.35)\end{array}$ & $\begin{array}{c}-0.3103 * * * \\
(-43.00)\end{array}$ & $\begin{array}{c}-0.2957 * * * \\
(-42.99)\end{array}$ \\
\hline Log(\# Accounts) & $\begin{array}{l}0.1382 * * * \\
\quad(4.07)\end{array}$ & $\begin{array}{c}-0.3573 * * * \\
(-8.73)\end{array}$ & $\begin{array}{l}0.0843 * * * \\
\quad(3.08)\end{array}$ & $\begin{array}{c}-0.3517 * * * \\
(-8.82)\end{array}$ & $\begin{array}{l}0.0683 * * \\
(2.13)\end{array}$ \\
\hline $\begin{array}{l}\text { Log(Bank-Firm } \\
\text { Relationship duration) }\end{array}$ & $\begin{array}{l}0.2078 * * * \\
(9.52)\end{array}$ & $\begin{array}{c}0.2226 * * * \\
(13.36) \\
\end{array}$ & $\begin{array}{c}0.2172 * * * \\
(11.01) \\
\end{array}$ & $\begin{array}{c}0.1788 * * * \\
(11.24) \\
\end{array}$ & $\begin{array}{l}0.1801 * * * \\
(8.04)\end{array}$ \\
\hline Type of Institution & $\begin{array}{l}\text { Private } \\
\text { Banks }\end{array}$ & $\begin{array}{l}\text { Private } \\
\text { Banks }\end{array}$ & $\begin{array}{l}\text { Private } \\
\text { Banks }\end{array}$ & $\begin{array}{l}\text { Private } \\
\text { Banks }\end{array}$ & $\begin{array}{l}\text { Private } \\
\text { Banks }\end{array}$ \\
\hline Adj $R^{2}$ & 0.6360 & 0.7096 & 0.6457 & 0.7137 & 0.6459 \\
\hline Fixed Effects & $\begin{array}{l}\text { Bank, } \\
\text { Firm, loan } \\
\text { rating, } \\
\text { Month x } \\
\text { type of } \\
\text { credit, } \\
\text { index rate }\end{array}$ & $\begin{array}{c}\text { Bank, Firm } \\
\text { x Year, } \\
\text { loan rating, } \\
\text { Month x } \\
\text { type of } \\
\text { credit, } \\
\text { index rate }\end{array}$ & $\begin{array}{c}\text { Bank x } \\
\text { Year, Firm, } \\
\text { loan rating, } \\
\text { Month x } \\
\text { type of } \\
\text { credit, } \\
\text { index rate }\end{array}$ & $\begin{array}{c}\text { Bank x } \\
\text { Year, Firm } \\
\text { x Year, } \\
\text { loan rating, } \\
\text { Month x } \\
\text { type of } \\
\text { credit, } \\
\text { index rate }\end{array}$ & $\begin{array}{l}\text { Bank, } \\
\text { Firm, loan } \\
\text { rating, } \\
\text { Month x } \\
\text { type of } \\
\text { credit, } \\
\text { index rate }\end{array}$ \\
\hline \# Observations & $12,844,787$ & $10,714,127$ & $12,844,749$ & $10,714,083$ & $10,714,083$ \\
\hline \# Bank FE & 128 & 127 & - & - & 127 \\
\hline \# Firm FE & $1,362,350$ & - & $1,362,346$ & - & $1,008,253$ \\
\hline \# Bank x Year FE & - & - & 938 & 919 & \\
\hline \# Firm x Year FE & - & $2,299,598$ & - & $2,299,587$ & \\
\hline \multicolumn{6}{|c|}{ 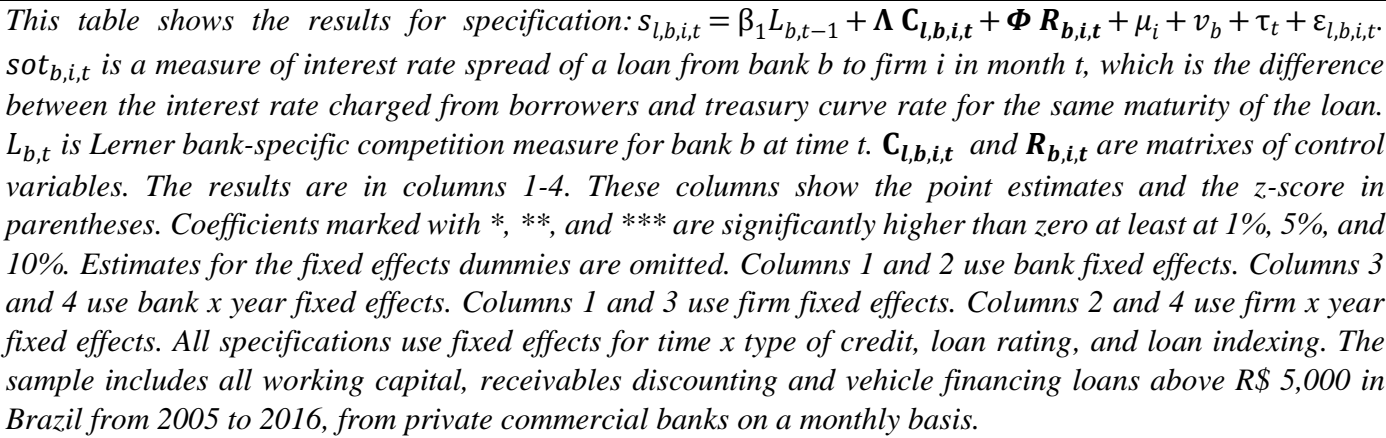 } \\
\hline
\end{tabular}


Table XII - Bank-specific Lerner Index and Spreads - State-Owned Banks

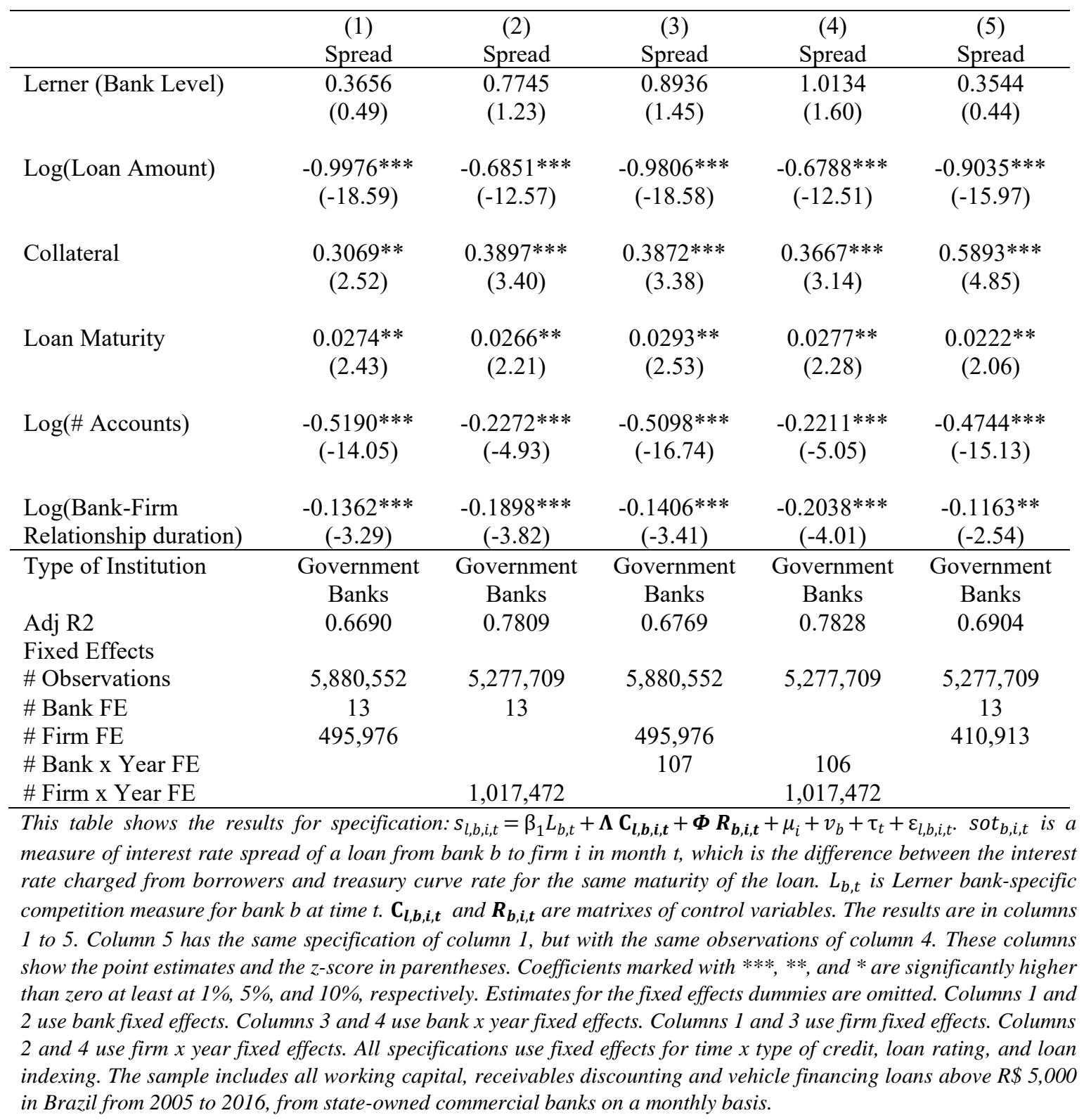


Table XIII - Bank-specific Lerner Index and Spreads - by Bank Size

\begin{tabular}{|c|c|c|}
\hline & $\begin{array}{c}(1) \\
\text { Spread }\end{array}$ & $\begin{array}{c}(2) \\
\text { Spread }\end{array}$ \\
\hline $\begin{array}{l}\text { Lerner Quintile } 2 \\
\text { (Between }-0.30 \text { and }-0.11 \text { ) }\end{array}$ & $\begin{array}{c}0.3749 \\
(0.97)\end{array}$ & $\begin{array}{l}-0.1901 \\
(-0.72)\end{array}$ \\
\hline $\begin{array}{l}\text { Lerner Quintile } 3 \\
\text { (Between }-0.11 \text { and }+0.00 \text { ) }\end{array}$ & $\begin{array}{l}0.2609 \\
(0.53)\end{array}$ & $\begin{array}{c}-0.1963 \\
(-0.88)\end{array}$ \\
\hline $\begin{array}{l}\text { Lerner Quintile } 4 \\
\text { (Between } 0.00 \text { and } 0.16 \text { ) }\end{array}$ & $\begin{array}{l}1.0340 * * \\
(2.22)\end{array}$ & $\begin{array}{l}0.6337 * * * \\
\quad(2.73)\end{array}$ \\
\hline $\begin{array}{l}\text { Lerner Quintile } 5 \\
\text { (Above } 0.16 \text { ) }\end{array}$ & $\begin{array}{l}1.5319^{* * *} \\
(2.68)\end{array}$ & $\begin{array}{l}0.9039 * * * \\
\quad(4.77)\end{array}$ \\
\hline Log(Loan Amount) & $\begin{array}{c}-5.1305 * * * \\
(-44.31)\end{array}$ & $\begin{array}{c}-1.4059 * * * \\
(-15.30)\end{array}$ \\
\hline Collateral & $\begin{array}{l}-0.2780 \\
(-1.20)\end{array}$ & $\begin{array}{l}-0.8539 * * * \\
(-3.74)\end{array}$ \\
\hline Loan Maturity & $\begin{array}{c}-0.3072 * * * \\
(-46.77)\end{array}$ & $\begin{array}{c}-0.0841 * * * \\
(-18.52)\end{array}$ \\
\hline Log(\# Accounts) & $\begin{array}{l}0.2719 * * * \\
\quad(7.49)\end{array}$ & $\begin{array}{l}-0.7403 * * * \\
\quad(-11.42)\end{array}$ \\
\hline $\begin{array}{l}\text { Log(Bank-Firm Relationship } \\
\text { duration) }\end{array}$ & $\begin{array}{c}0.2349 * * * \\
(9.28)\end{array}$ & $\begin{array}{c}0.2903 * * * \\
(23.20)\end{array}$ \\
\hline Type of Institution & $\begin{array}{c}\text { Large } \\
\text { Private Banks }\end{array}$ & $\begin{array}{c}\text { Non-large } \\
\text { Private Banks }\end{array}$ \\
\hline $\begin{array}{l}\text { Adj R2 } \\
\text { Fixed Effects }\end{array}$ & $\begin{array}{l}0.6344 \\
\text { Bank, Firm, loan } \\
\text { rating, Month x } \\
\text { type of credit, } \\
\text { index rate }\end{array}$ & $\begin{array}{l}0.8076 \\
\text { Bank, Firm, loan } \\
\text { rating, Month x } \\
\text { type of credit, } \\
\text { index rate }\end{array}$ \\
\hline $\begin{array}{l}\text { \# Observations } \\
\text { \# Bank FE } \\
\text { \# Firm FE } \\
\text { \# Firm FE }\end{array}$ & $\begin{array}{c}11,606,958 \\
6 \\
1,285,158 \\
1,285,158\end{array}$ & $\begin{array}{c}1,064,257 \\
125 \\
149,228 \\
149,228\end{array}$ \\
\hline
\end{tabular}




\section{Appendix II - Marginal Cost Estimation}

In this appendix, we describe how to compute the marginal cost, which is a necessary input for the Lerner Index. Marginal cost is not directly observable for a particular bank or individual products supplied by banking firms. This is done empirically by estimating the parameters of a total cost function from individual bank data and deriving the marginal costs from the equation parameters.

We estimate such measures by specifying the commonly-used translog functional form for the cost function because it provides a convenient framework for analyzing banking competition in a multioutput context. The objective of normalizing the dependent variable and one input price $\left(w_{1 i t}\right)$ by another input price $\left(w_{2 i t}\right)$ is to ensure linear homogeneity (see Berger et al., 2009, for further details).

We estimate the TCF using three outputs and two input (production) factors, along with control variables (time dummies and the provision for non-performing loans). Our TCF specification is the following:

$$
\begin{gathered}
\operatorname{Ln}\left(\frac{T C_{i t}}{w_{2 i t}}\right)=\delta_{0}+\sum_{j} \delta_{j} \operatorname{Ln}\left(y_{j i t}\right)+ \\
\sum_{j} \sum_{k} \delta_{j k} \operatorname{Ln}\left(y_{j i t}\right) \operatorname{Ln}\left(y_{k i t}\right)+\beta_{1} \operatorname{Ln}\left(\frac{w_{1 i t}}{w_{2 i t}}\right)+ \\
\frac{1}{2} \beta_{11} \operatorname{Ln}\left(\frac{w_{1 i t}}{w_{2 i t}}\right)^{2}+\sum_{j} \theta_{j} \ln \left(y_{j i t}\right) \operatorname{Ln}\left(\frac{w_{1 i t}}{w_{2 i t}}\right)+\psi y_{1 i t} p_{i t}+ \\
\phi p_{i t}+\sum_{t} \tau_{t} D_{t}+\sum_{t} \Gamma_{t}\left(D_{t} y_{1 i t}\right)+\varepsilon_{i t}
\end{gathered}
$$

Where

$T C_{i t}$ are total costs of bank $i$, in period $t$ (quarter);

$y_{\text {kit }}$ measure three bank outputs, respectively credit operations without provisions for non-performing loans $(k=1)$, liquid assets $(k=2)$ and other assets $(k=3)$;

$w_{j i t}$ are two input prices for bank $i$ in quarter $t$, where input $j=1$ are the administrative costs as a percentage of total assets and $j=2$ is financial intermediation $\operatorname{costs}^{18}$

$p_{i t}$ is the provision for non-performing loans of bank $i$ on quarter $t$;

$D_{t}$ are time dummies for each quarter $t$. (We have 48 quarters in total)

\footnotetext{
${ }^{18}$ Ratio of interest expenses to total deposits
} 
$\varepsilon_{i t}=v_{i}+u_{i t}$ is the error term, with $u_{i}$ having the following properties: 1) $u_{i} \sim$ $\mathrm{N}(0, \sigma) ; 2) \operatorname{var}\left(u_{i}\right)=\sigma^{2}$; and $v_{i}$ measures the inefficiency of financial institution, with a half-normal distribution.

Once we have the coefficients of the TCF, we can calculate marginal costs $M C_{1 i t}$ for bank $i$ at time $t$ as:

$$
\begin{gathered}
M C_{1 i t}=\frac{\left(\frac{T C_{i t}}{w_{2 i t}}\right)}{y_{1 i t}}\left[\delta_{1}+2 \delta_{11} L n y_{1 i t}+\delta_{12} L n y_{2 i t}+\delta_{13} L n y_{3 i t}\right. \\
\left.+\theta_{1} \operatorname{Ln}\left(\frac{w_{1 i t}}{w_{2 i t}}\right)\right]+\sum_{t} \Gamma_{t} D_{t}
\end{gathered}
$$

